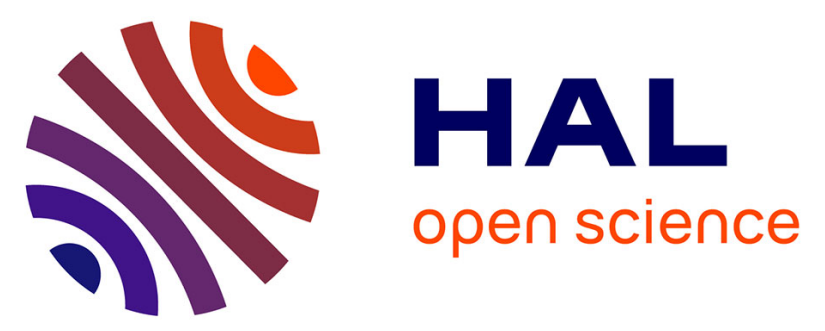

\title{
Unusual microbial mat-related structural diversity 2.1 billion years ago and implications for the Francevillian biota
}

\author{
Jérémie Aubineau, Abderrazak El Albani, Ernest Chi Fru, Murray K. \\ Gingras, Yann Batonneau, Luis Buatois, Claude Geffroy, Jérôme Labanowski, \\ Claude Laforest, Laurent Lemée, et al.
}

\section{To cite this version:}

Jérémie Aubineau, Abderrazak El Albani, Ernest Chi Fru, Murray K. Gingras, Yann Batonneau, et al. Unusual microbial mat-related structural diversity 2.1 billion years ago and implications for the Francevillian biota. Geobiology, 2018, 16 (5), pp.476-497. 10.1111/gbi.12296 . insu-01869078

\section{HAL Id: insu-01869078 https://hal-insu.archives-ouvertes.fr/insu-01869078}

Submitted on 17 Sep 2018

HAL is a multi-disciplinary open access archive for the deposit and dissemination of scientific research documents, whether they are published or not. The documents may come from teaching and research institutions in France or abroad, or from public or private research centers.
L'archive ouverte pluridisciplinaire HAL, est destinée au dépôt et à la diffusion de documents scientifiques de niveau recherche, publiés ou non, émanant des établissements d'enseignement et de recherche français ou étrangers, des laboratoires publics ou privés. 


\title{
Unusual microbial mat-related structural diversity 2.1 billion years ago and implications for the Francevillian biota
}

\author{
Jérémie Aubineau $^{1}$ | Abderrazak El Albani ${ }^{1}$ (D) | Ernest Chi Fru ${ }^{2}$ | Murray Gingras $^{3}$ | \\ Yann Batonneau $^{1}$ | Luis A. Buatois ${ }^{4}$ | Claude Geffroy $^{1}$ | Jérôme Labanowski ${ }^{1}$ | \\ Claude Laforest $^{1}$ | Laurent Lemée $^{1}$ | Maria G. Mángano ${ }^{4}$ | Alain Meunier ${ }^{1}$ | \\ Anne-Catherine Pierson-Wickmann ${ }^{5}$ | Philippe Recourt $^{6}$ | Armelle Riboulleau ${ }^{6}$ | \\ Alain Trentesaux $^{6}$ | Kurt O. Konhauser ${ }^{3}$
}

${ }^{1}$ UMR CNRS IC2MP 7285, University of

Poitiers, Poitiers, France

${ }^{2}$ School of Earth and Ocean Sciences, Cardiff University, Cardiff, UK

${ }^{3}$ Department of Earth and Atmospheric Sciences, University of Alberta, Edmonton,

Alberta, Canada

${ }^{4}$ Department of Geological Sciences, University of Saskatchewan, Saskatoon, Saskatchewan, Canada

${ }^{5}$ Department Geosciences, UMR 6118, University of Rennes 1, Rennes, France

${ }^{6}$ UMR 8187 LOG CNRS, University of Lille, ULCO, Villeneuve d'Ascq, France

\section{Correspondence}

Abderrazak El Albani, UMR CNRS IC2MP 7285, University of Poitiers, 86073 Poitiers, France.

Email: abder.albani@univ-poitiers.fr

\section{Funding information}

European Research Council ERC Seventh Framework Program (FP7), Grant/Award Number: 336092; Natural Sciences and Engineering Research Council (NSERC)

\begin{abstract}
The 2.1-billion-year-old ( $\mathrm{Ga}$ ) Francevillian series in Gabon hosts some of the oldest reported macroscopic fossils of various sizes and shapes, stimulating new debates on the origin, evolution and organization of early complex life. Here, we document ten representative types of exceptionally well-preserved mat-related structures, comprising "elephant-skin" textures, putative macro-tufted microbial mats, domal buildups, flat pyritized structures, discoidal microbial colonies, horizontal mat growth patterns, wrinkle structures, "kinneyia" structures, linear patterns and nodule-like structures. A combination of petrographic analyses, scanning electron microscopy, Raman spectroscopy and organic elemental analyses of carbon-rich laminae and microtexture, indicate a biological origin for these structures. The observed microtextures encompass oriented grains, floating silt-sized quartz grains, concentrated heavy minerals, randomly oriented clays, wavy-crinkly laminae and pyritized structures. Based on comparisons with modern analogues, as well as an average $\delta^{13} \mathrm{C}$ organic matter $\left(\mathrm{C}_{\text {org }}\right)$ composition of $-32.94 \pm 1.17 \%$ o (1 standard deviation, $S D$ ) with an outlier of $-41.26 \%$, we argue that the mat-related structures contain relicts of multiple carbon pathways including heterotrophic recycling of photosynthetically derived $\mathrm{C}_{\text {org }}$. Moreover, the relatively close association of the macroscopic fossil assemblages to the microbial mats may imply that microbial communities acted as potential benthic $\mathrm{O}_{2}$ oases linked to oxyphototrophic cyanobacterial mats and grazing grounds. In addition, the mat's presence likely improved the preservation of the oldest large colonial organisms, as they are known to strongly biostabilize sediments. Our findings highlight the oldest community assemblage of microscopic and macroscopic biota in the aftermath of the "Great Oxidation Event," widening our understanding of biological organization during Earth's middle age.
\end{abstract}

\section{KEYWORDS}

bacterial mats, Gabon, geochemistry, geomicrobiology, palaeoenvironment, palaeoproterozoic 


\section{1 | INTRODUCTION}

The Paleoproterozoic Era hosted one of the most important geochemical events in Earth's history, marked by a measurable accumulation of atmospheric oxygen, the so-called "Great Oxidation Event" (GOE) between 2.45 and 2.32 billion years ago (Ga). Evidence for the GOE comes from the disappearance of detrital pyrite, uraninite and siderite from fluvial and deltaic deposits, an increase in the retention of iron in palaeosols, an enrichment of $\mathrm{Cr}$ and $\mathrm{U}$ in iron formations, and perhaps most importantly, the disappearance of sedimentary sulphur isotope mass-independent (S-MIF) anomalies indicative of atmospheric $\mathrm{SO}_{2}$ processing in the absence of appreciable ozone (Bekker et al., 2004; Farquhar, Zerkle, \& Bekker, 2011; Holland, 2002; Konhauser et al., 2011; Lyons, Reinhard, \& Planavsky, 2014; Partin, Lalonde et al., 2013). In the wake of the GOE, large positive excursions in the $\delta^{13} \mathrm{C}$ of marine inorganic carbon, during the "Lomagundi Event" ca. 2.22-2.1 Ga (Karhu \& Holland, 1996), are believed to reflect large-scale burial of organic matter in marine sediments (Bekker \& Holland, 2012; Berner, 2004). New evidence suggests that the "Lomagundi Event" ended with a drastic drop in Earth's oxygen content (e.g., Partin, Bekker et al., 2013), perhaps related to large-scale oxidation of organic carbon (Canfield et al., 2013) and/or changes in ocean biogeochemical processes that may have inhibited primary productivity (Chi Fru et al., 2015).

The Francevillian sedimentary rocks ca. $2.1 \mathrm{Ga}$ record these biogeochemical fluctuations in Earth's oxygen accumulation dynamics through extreme excursions in the carbon cycle, in addition to hosting the oldest large colonial macroorganisms (El Albani et al., 2010, 2014). Major elements, trace metals, organic carbon and isotope analyses offer constraints on the basin geochemistry, revealing variations from the base to the top that are linked to sea level changes (Bankole et al., 2016; Canfield et al., 2013). The Lower Francevillian fluviatile rocks were deposited in oxygenated waters (Bankole et al., 2016), whereas the Upper Francevillian marine rocks were deposited in oxic, ferruginous and euxinic waters (Canfield et al., 2013). The large macrofossils are highly variable in terms of size, shape and pyritization process being represented by lobate, elongated and rodshaped as well as disc-shaped morphotypes. The pyritization process did not fully occur in the circular discs, indicating that their organic composition differs from that of pyritized specimens (El Albani et al., 2010, 2014). In addition, some carbonaceous spheroidal microstructures have also been reported as organic-walled acritarchs that might have a planktonic origin.

Of late, microbial fossils were found in the Francevillian sequence, including putative bacteriomorphous structures (Dubois et al., 2015) and a Gunflint-type assemblage of microfossils in the stromatolitic units (Lekele Baghekema et al., 2017). The presence of colonial macroorganisms and microfossils makes the Francevillian biota unique, but interestingly, evidence of microbial mats has never been demonstrated. In this work, we describe for the first time ever microbial mat-related structures (MRS) from 2.1 Ga siliciclastic sandstones and black shales from the FB2 Member of the Francevillian basin, Gabon. MRS are physical remains of destroyed mats and structures associated with decay, instead of well-preserved mat growth features (Eriksson et al., 2010). Their sedimentary features are preserved because microbes secrete extracellular polymeric substances (EPS), an adhesive mucilage (Decho, 2000), that provide a coherent and protective coating that is unlikely to arise in sediments without a biological input (Gerdes, Klenke, \& Noffke, 2000; Gerdes et al., 1993; Noffke, 2010; Porada \& Bouougri, 2007).

Microbial life in the Paleoproterozoic has been poorly described (Davies, Liu, Gibling, \& Miller, 2016) even though existing palaeontological and biogeochemical evidence points towards the existence of significant microbial diversity previously in the Archean. Through a combination of macroscopic and microtexture analyses, petrographic, geochemical, organic elemental analyses and stable carbon isotope composition of bulk organic matter, we compare modern and fossil mat-related structures, to characterize the marine palaeoenvironment in which the putative microbial mats formed. The data reveal the biogenicity of these structures, adding new insights into the origins of the Francevillian biota (El Albani et al., 2010, 2014; Ngombi Pemba, 2014; Ossa Ossa, 2010; Parize, Feybesse, Guillocheau, \& Mulder, 2013; Reynaud et al., 2017). It is important that, we assessed and described the organizational, ecological and taphonomical processes that led to the development and preservation of the unique Francevillian biota.

\section{2 | GEOLOGICAL BACKGROUND}

The Francevillian basin, located in the south-eastern part of the Republic of Gabon (Figure 1a), is a $35,000 \mathrm{~km}^{2}$ depression comprising 2.2-2.0 Ga marine sedimentary rocks that unconformably overly an Archean basement (Weber, 1969). Petrographic and geochemical analyses indicate that the Francevillian sediments were not affected by metamorphic transformation (maximum temperature $100^{\circ} \mathrm{C}$; Gauthier-Lafaye \& Weber, 1989; Ngombi-Pemba, Albani, Meunier, Grauby, \& Gauthier-Lafaye, 2014), resulting in the preservation of seawater composition at the time when deposition took place. Moreover, carbon isotopic and redox sensitive element compositions suggest that the "Lomagundi Event" was a global event (Canfield et al., 2013).

The basin fill, composed of siliciclastic fluvial and marine deposits that are 1,000-2,500 $\mathrm{m}$ thick, is subdivided into four major lithostratigraphic formations, FA to FD (Figure 1b; Weber, 1969; Gauthier-Lafaye \& Weber, 1989; Gauthier-Lafaye, 2006; El Albani et al., 2010, 2014). Fluviatile to deltaic conglomeratic sandstones, overlain by marine sandstones deposited in a tidal environment (i.e., syntectonic filling), make up the FA Formation, with the overlying sediments hosting diagenetic uranium ore deposits and the natural nuclear fission reactors of Oklo (Gauthier-Lafaye \& Weber, 1989, 2003). The marine-dominated FB sequence rests unconformably on FA. The former was deposited below storm wave base during basin deepening and is subdivided into the FB1 ( $a, b$ and c) and FB2 ( $a$ and b) subunits. The FB1a and FB1b subunits are composed of interbedded shales, sandstones and conglomerate, 
(a)

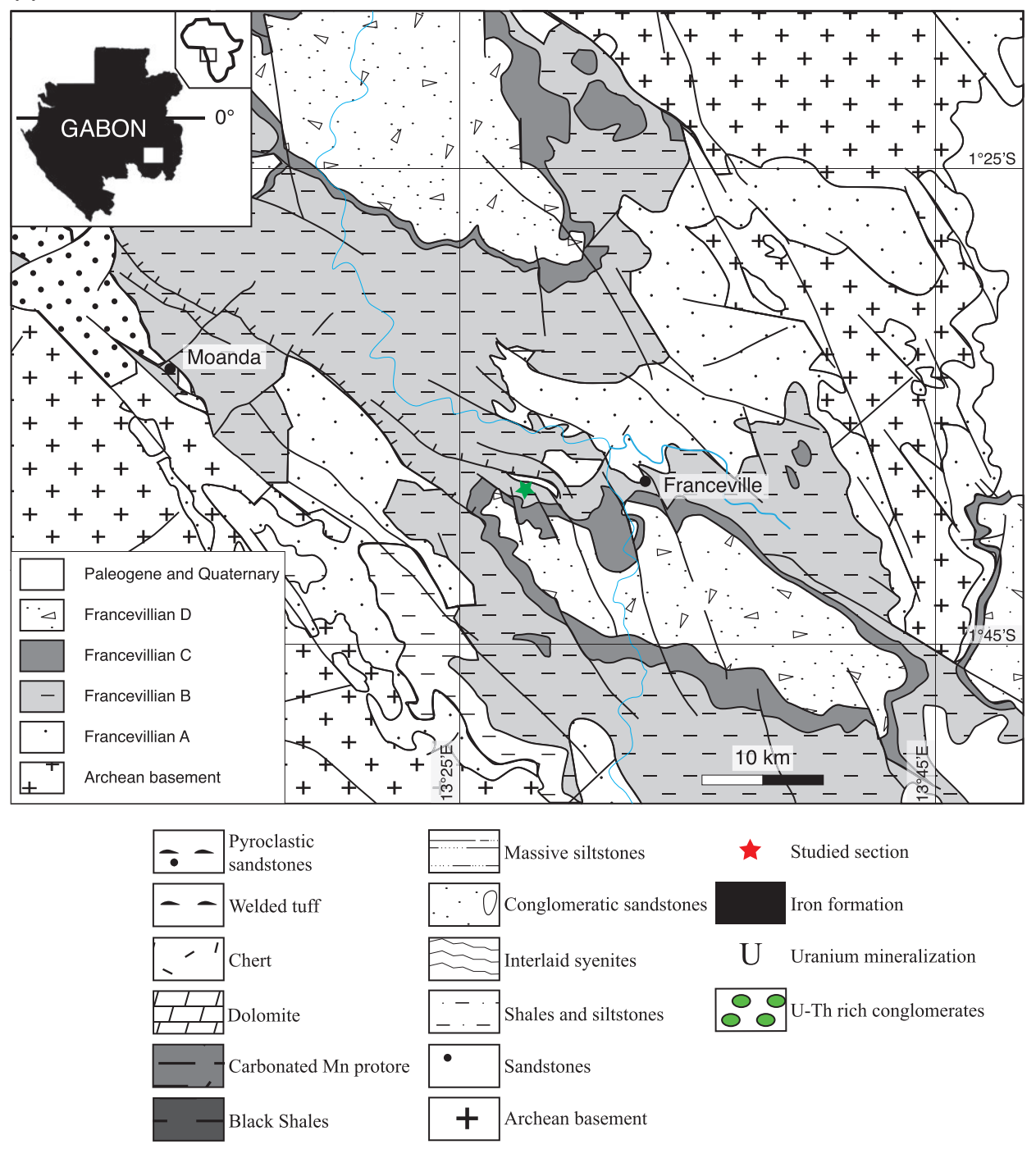

(b)

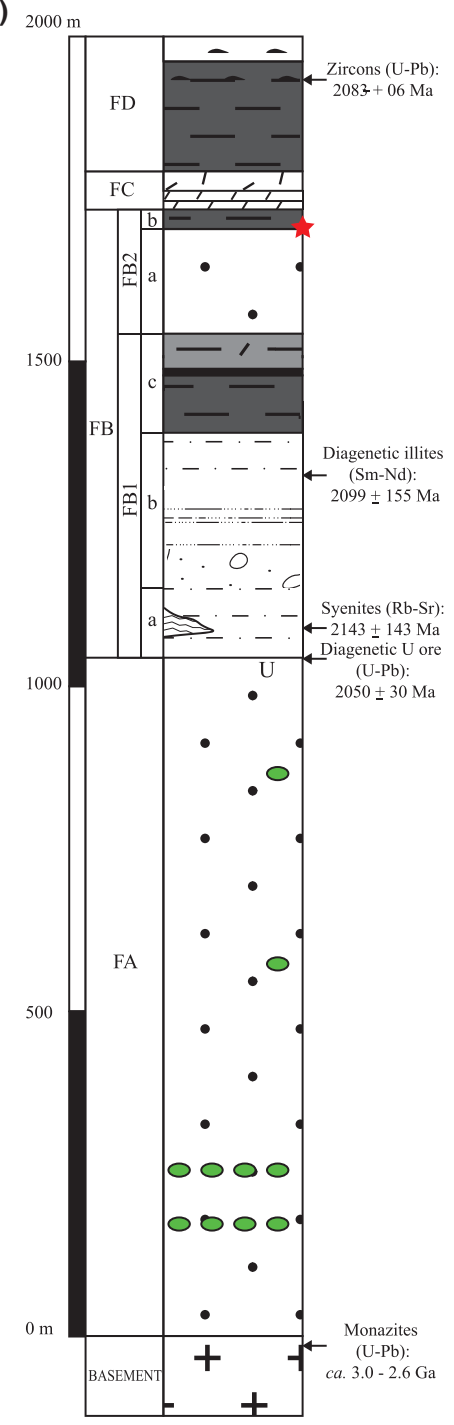

FIGURE 1 Geological map and lithostratigraphic column. (a) Geological map of the Francevillian basin. The studied quarry is Moulendé (green star). Geological map adopted from (Bouton et al., 2009). (b) Synthetic lithostratigraphy of the Francevillian series. Four sedimentary units rest unconformably on Archean rocks. The red star indicates the detailed lithostratigraphic column observed in the Moulendé quarry (Figure 2) [Colour figure can be viewed at wileyonlinelibrary.com]

stacked into fining upwards packages, while the overlying FB1c subunit mainly consists of black shales with a thin iron formation, likely corresponding to a maximum flooding surface. This is then overlain by thick $\mathrm{Mn}$-rich carbonates. Massive sandstone beds of the FB2a subunit, probably deposited in channels near the fairweather wave base, are capped by thinly laminated black shales that are $5 \mathrm{~m}$ thick, and interbedded with thin siltstone layers (FB2b), presumably deposited by waning storm surges. Outcrops of the FB2b subunit are scarce but host the well-known colonial macroorganisms described in El Albani et al. (2010, 2014). The overlying FC Formation consists of dolomite and thickly-banded stromatolitic cherts that were deposited under shallow water conditions (Bertrand-Sarfati \& Potin, 1994). The uppermost FD Formation consists mainly of black shales, with pyroclastic material at the top deposited in a deep marine environment (GauthierLafaye \& Weber, 2003).
The Francevillian basin has been intensively studied because of economic interests in their uranium and manganese ore content (Gauthier-Lafaye \& Weber, 1989, 2003). Therefore, various ages have been obtained for the Francevillian sediments. For example, monazites contained in Archean plutonic rocks from the Chaillu massif close to the FA Formation transition provided U-Pb ages of $2,998 \pm 25 \mathrm{Ma}$ to $2,621 \pm 30 \mathrm{Ma}$ (Mouélé et al., 2014). A U-Pb age of 2,050 $\pm 30 \mathrm{Ma}$ reported for uranium mineralization, delineates early diagenesis at the FA-FB boundary (Gancarz, 1978). Coarsegrained syenites of the N'Goutou volcanic complex, in the northern part of the Republic of Gabon, that are interlayered with rocks at the base of the FB1 sequence, yield an Rb-Sr age of 2,143 $\pm 143 \mathrm{Ma}$ (Bonhomme, Gauthier-Lafaye, \& Weber, 1982). It is considered that these volcanic rocks were formed simultaneously with the sedimentary rocks. Diagenetic illites from the top of the FB1b subunit have been dated at 2,099 $\pm 115 \mathrm{Ma}$ using the Sm-Nd method (Bros, Stille, 


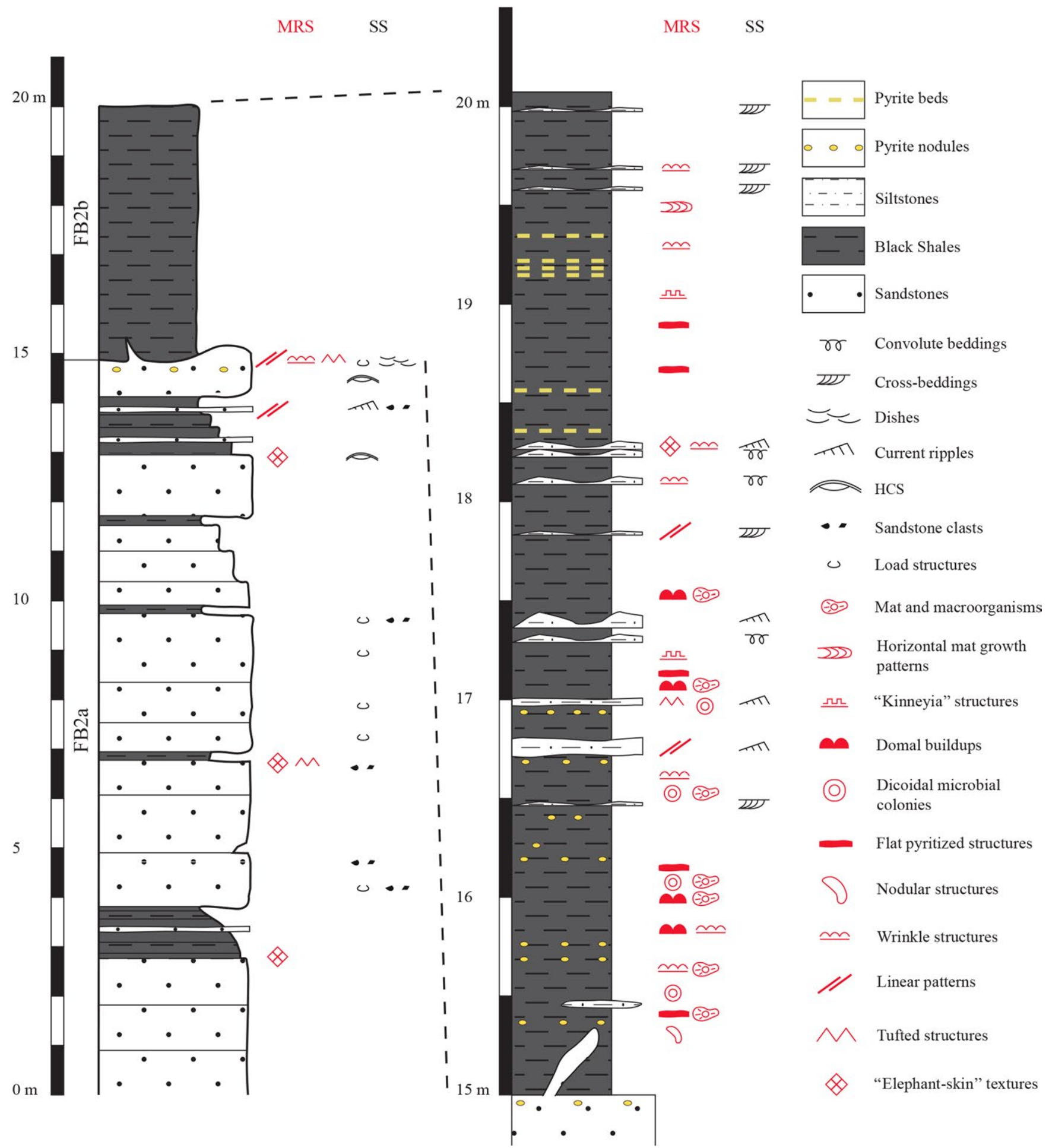

FIGURE 2 Detailed lithostratigraphic column. Composite columnar section of the Moulendé quarry in the FB2 Member showing the vertical distribution of ten representative types of mat-related structures (MRS) and sedimentary structures (SS) [Colour figure can be viewed at wileyonlinelibrary.com]

Gauthier-Lafaye, Weber, \& Clauer, 1992). At last, recent dating of zircons from welded tuffs near the top of the FD Formation produced a U-Pb age of 2,083 $\pm 6 \mathrm{Ma}$ (Horie, Hidaka, \& Gauthier-Lafaye, 2005).

The Paleoproterozoic Francevillian MRS were discovered in the Moulendé quarry, the same fossiliferous quarry where large colonial organisms have been reported (El Albani et al., 2010, 2014). MRS are heterogeneously distributed in the Upper FB2a subunit, as well as in the overlying laminated black shale. The latter is $5 \mathrm{~m}$ thick and forms the FB2b subunit (Figure 2), covering a $\sim 20 \mathrm{~m}$ thick host interval. 


\section{3 | METHODS}

\section{1 | Sampling and sample preparation}

About one hundred samples were collected in order to describe large-scale variability in morphology, structural organization and diversity from outcrops localized in one locality over several years (Figure 1). All samples were logged to provide information on their spatial and time repartitions of the studied area (Figure 2), and then photographed at the University of Poitiers using a Nikon Europe D610 digital single-lens reflex camera equipped with a Nikon AF-S 24-120 mm f/4G ED VR lens. Polished slabs were observed using a ZEISS Discovery.V8 stereoscope combined with Axio Cam ERc 5s microscope camera. Based on this pre-screening analysis, representative samples were selected and powdered in an agate mortar for elemental and carbon isotope systematics.

\section{2 | Petrographic and mineralogical analysis}

Petrographic and mineralogical examinations were performed by transmitted and reflected light on eight polished thin sections using a Nikon ECLIPSE E600 POL microscope equipped with a Nikon Digital Sight DS-U1 camera and NIS-Element D software for scanning observations. Seven thin sections were carbon coated and examined for textural and compositional analyses using a FEI Quanta 200 scanning electron microscope (SEM) at the University of Lille 1. The SEM, coupled to Rontec energy-dispersive spectra (EDS) for semi-quantitative mineral analysis in backscattered electron mode (BSE), was operated at $15 \mathrm{kV}$ accelerating volts and a $1 \mathrm{nA}$ beam current at a working distance of $10.5 \mathrm{~mm}$.

\section{3 | Carbon analysis}

Raman spectroscopy was used to determine the composition of carbon preserved within the MRS on two representative samples. Analyses were carried out at the University of Poitiers with a HORIBA JOBIN YVON Labram HR800UV, an integrated Olympus confocal microscope coupled to a Peltier-cooled CCD detector. All analyses were performed by means of $514.5 \mathrm{~nm} \mathrm{Ar}{ }^{+}$laser of $1 \mathrm{~mW}$, $200 \mu \mathrm{m}$ confocal hole, 1,800 grooves/mm grating. Data recording and treatment were done with LabSpec 5 software.

Ten representative samples, composed of five mat samples and five associated surrounding sediments, were crushed for the determination of the elemental content of associated organic matter, as well as carbon and sulphur composition, at the University of Poitiers. Analyses were performed using a CHNS analyser, model FlashEA 1112 (Thermofisher Scientific) by flash dynamic combustion at $970^{\circ} \mathrm{C}$ under a constant flow of helium. Data were recorded using Eager 300 software. A calibration curve was obtained with sulphanilamide and BBOT-2,5-Bis(5-tert-butyl-benzoxazol-2-yl) thiophene-before each analysis. The results of carbon contents include both inorganic and organic carbon, but petrographic analyses showed that calcium carbonate and dolomite concentrations were low.
Stable carbon isotope measurements $\left({ }^{12} \mathrm{C},{ }^{13} \mathrm{C}\right)$ of organic matter from 14 mat samples (from both FB2a and FB2b subunits) were conducted at the Stable Isotopes Laboratory of UMR Pegase (INRA Rennes, France), using an elemental analyser coupled with an isotope ratio mass spectrometer (IRMS; VG Isoprime; UMR PEGASE-INRA Rennes). More than $500 \mathrm{mg}$ of fine-grained powders were analysed and loaded in tin capsules for each sample. IAEA-C6 (sucrose ANU, $\delta^{13} \mathrm{C}=-10.63 \%$ ), USGS-24 (graphite, $\delta^{13} \mathrm{C}=-15.98 \%$ ), USGS-40 (glutamic acid, $\delta^{13} \mathrm{C}=-26.32 \%$ ) and Urea Isotopic Working Standard $\left(\delta^{13} \mathrm{C}=-38.3 \%\right.$ ) were used as reference standards. Data are expressed as delta values (\%o) relative to Vienna Pee Dee Belemnite (V-PDB). No correction was added to the measured values, and the analytical uncertainty is estimated to be lower than $0.2 \%$.

\section{4 | FACIES ANALYSIS OF THE MOULENDÉ QUARRY}

The Moulendé quarry has been examined over an area of $\sim 5$ ha, for a total of nine studied outcrops (Figure 3a). Amongst them, the F8 outcrop (Figure $3 \mathrm{a}-\mathrm{c}$ ) was logged in detail because of its well-exposed strata and sedimentary structures. It is the only outcrop where the FB2a-FB2b transition is observed with accompanying black shale deposits. Lithological composition, vertical facies relationships and sedimentary features allow recognition of two depositional facies from the MRS-bearing strata.

\section{1 | Facies 1}

Thick-bedded, coarse-grained sandstones represent the main facies of the Moulendé quarry. These deposits are commonly referred to the Poubara sandstones (FB2a subunit; Figures 2 and 3a-c). This facies is $15 \mathrm{~m}$ thick in the quarry, as well as in the closest drill core (GR5; Azziley Azzibrouck, 1986), but could be up to $100 \mathrm{~m}$ thick elsewhere in the basin (Weber, 1969). Interbedded thin-bedded, coarse-grained sandstones and laminated black shales form heterolithic beds. The uppermost massive sandstone bed is laterally heterogeneous in thickness and its bedding surface is undulatory. At the top of several massive sandstone beds, sedimentary features, including load structures, sandstone clasts and water escape structures, such as dishes, are present. These beds occasionally contain dm-scale hummocky cross-stratification (HCS), restricted to the upper part of the succession (Figures 2 and 3d; Reynaud et al., 2017).

\subsection{Facies 2}

Numerous thin-bedded, parallel-laminated black shales with interbeds of siltstones lie conformably upon Facies 1 . They form stacks of variable thickness in the upper part of the studied succession and are about $5 \mathrm{~m}$ thick. Connected to the underlying facies and approximately $0.4 \mathrm{~m}$ in height, a sandstone dyke cross-cuts these multilayered black shales (Figures 2 and 3e). There is no evidence of fracturing along the dyke, indicating that the sediments were not consolidated 

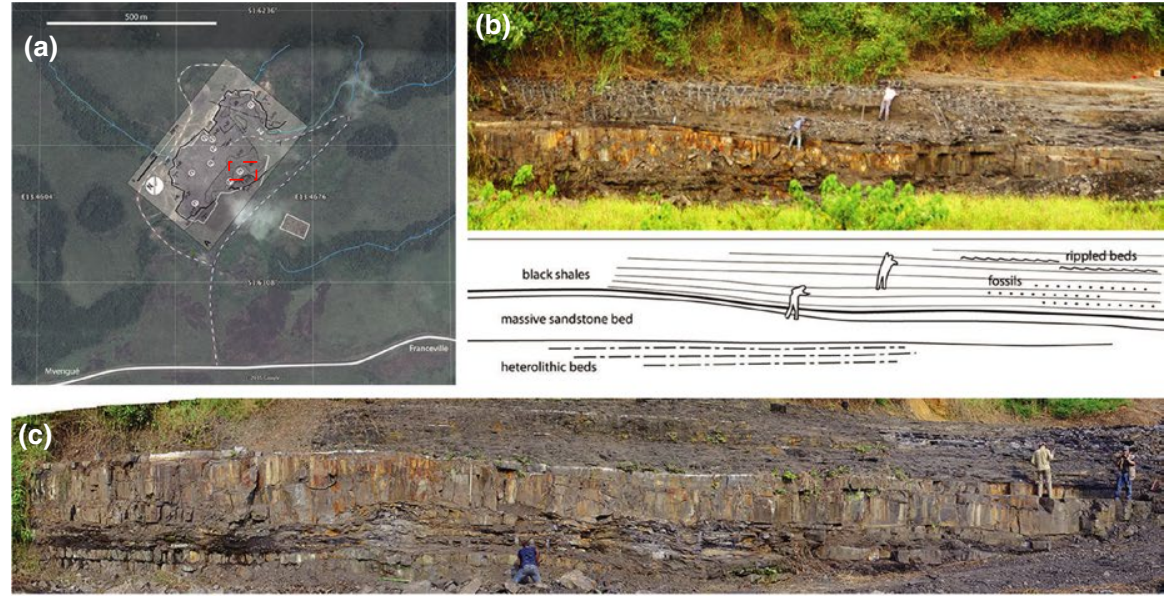

FIGURE 3 Plane view and outcrop pictures of sedimentary facies in the Moulendé quarry. (a) Representation of the quarry from plane view. Red box indicates the main studied outcrop in B (F8). F = outcrops. (b) Details of the bedding geometry at the transition between massive sandstone beds and thinly laminated black shales. (c) Closer view of $B$. (d) Cross-section view of decimetre scale hummocky crossstratifications (HCS), FB2a subunit. (e) Sandstone dyke, FB2a-FB2b transition. Coin diameter: $\sim 2 \mathrm{~cm}$. (f) Cross-section view of convolute structures, FB2b subunit. (g) Bedding plane view of interference ripples, FB2b subunit. (h) Longitudinal view of dark-coloured convex laminae associated with $\mathrm{cm}$-scale foreset beds, FB2b subunit [Colour figure can be viewed at wileyonlinelibrary.com]
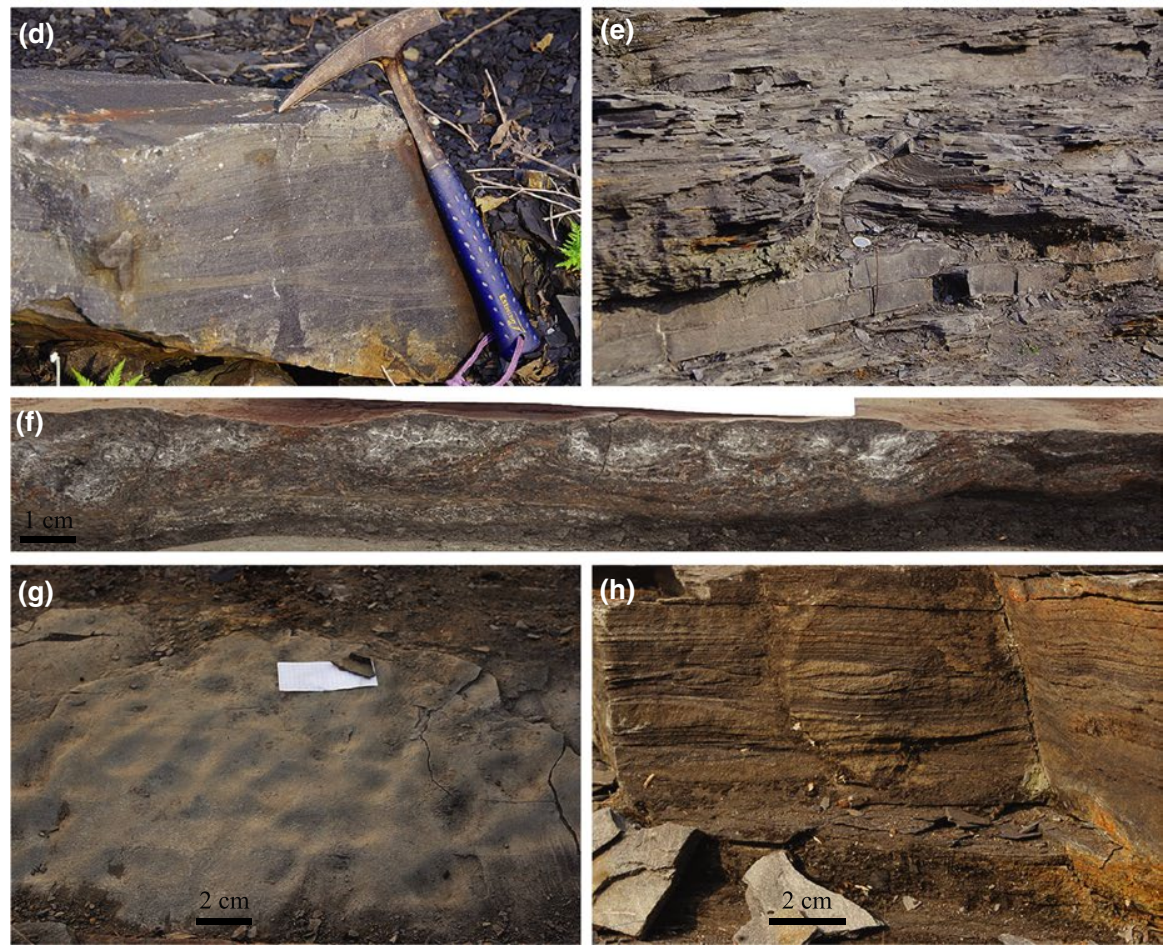

prior to injection. The main component of facies 2 is characterized by rhythmic successions of $\mathrm{mm}$-scale light and dark laminae of siltstones and shales. Small-scale cross-laminae are found within mm-thick interbedded siltstones. Load-shaped and flame-shaped structures forming convolute bedding (Figures 2 and $3 f$ ) are observed in interbedded medium-to-coarse-grained siltstone beds ranging from 2 to $5 \mathrm{~cm}$ in thickness. Interference ripples are also observed, indicating palaeowaves coming from two directions (Figures 2 and 3g). At last, a dm-scale bed containing dark-coloured convex laminae associated with $\mathrm{cm}$-scale current ripples comprise the thickest interbedded coarse-grained siltstones (Figures 2 and $3 \mathrm{~h}$ ).

\section{3 | Interpretations}

The variation in thickness of the uppermost massive sandstone level (at $\sim 15 \mathrm{~m}$ in the stratigraphy) may be related to detachment folds and troughs later infilled by overlying sediments (Reynaud et al.,
2017). Sudden and rapid deposition of coarse-grained sediments produce load and dish structures by immediate dewatering (Reineck \& Singh, 1980). Rapid sedimentation also results in sandstone dykes formed by elevated pore pressures leading to fluidization of the unconsolidated sediment. In addition, conditions that are favourable for the formation of HCS are commonly found between the fairweather and storm wave base (Immenhauser, 2009). Various interpretations have been proposed for the palaeoenvironmental setting of the FB2a subunit. They range from a deltaic palaeoenvironment subjected to tidal influence (El Albani et al., 2010; Ossa Ossa, 2010), to a shoreface palaeoenvironmental setting (Ngombi Pemba, 2014), to a turbidite lobe setting in waters deeper than 200 m (Parize et al., 2013). Reynaud et al. (2017) showed that the Poubara sandstones are composed of high-density sediment gravity flow deposits, emplaced during a forced regressive system tract. These authors underline that the Francevillian basin was likely isolated because of the absence of wave deposits. They also noticed the presence 
of linguoid and interference ripples that is consistent with shallow water settings.

Thinly laminated black shales are deposited in a relatively quiet water setting but interrupted by quickly deposited supplies of millimetre-to-centimetre-scale siltstones. These laminae host many sedimentary structures that indicate a strong current. Reynaud et al. (2017) suggest that these sediments were deposited close to the maximum regressive surface whereas Parize et al. (2013) argue for the deposition of turbidites on an upper slope setting.

\section{5 | MAT-RELATED STRUCTURES (MRS) IN THE FB2 MEMBER}

The MRS documented here come from a 20 m thick interval of the FB2 sequence (Figure 2). Some specimens are entirely or partially pyritized, while others display a few isolated pyrite grains within the mat layers. Following the classification scheme by Sarkar, Bose, Samanta, Sengupta, and Eriksson (2008), the Francevillian MRS are divided into two major categories: (a) mat-layer structures, representing potential in situ growth of a microbial mat (Figures 4 and 5; Figure S1) and (b) mat-protected structures (Figure 6), possibly formed by abiotic processes but requiring the protection of a microbial mat (Davies et al., 2016).

\section{1 | Mat-layer structures}

This group of MRS represents the "mat-layer itself that may be intact, deformed or rafted" (Sarkar et al., 2008). In this work, we interpret well-preserved, intact mat growth according to the following criteria.
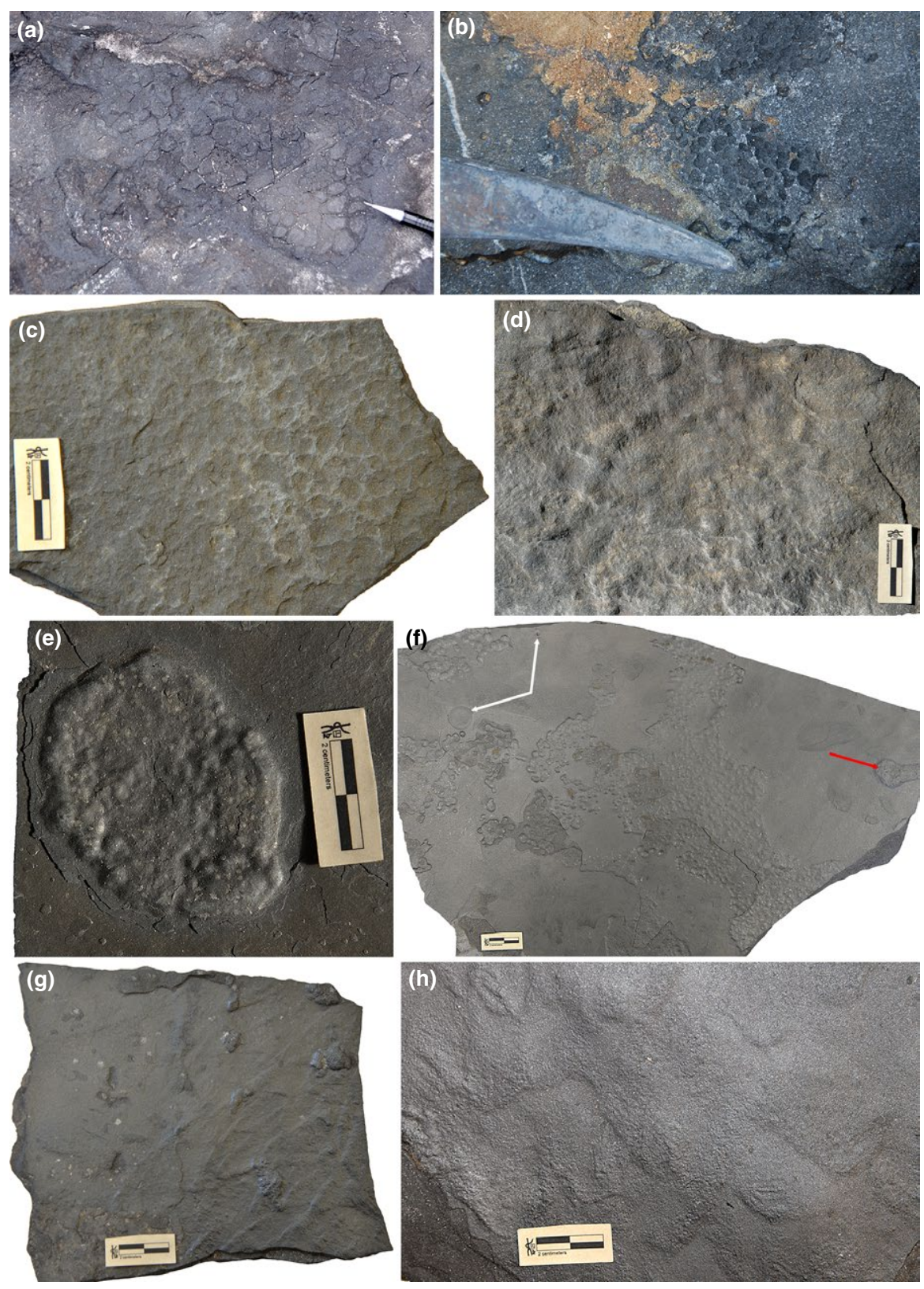

FIGURE 4 Microbial mat structures in the Francevillian B Formation (FB2): Mat-layer structures. $(\mathrm{a}-\mathrm{c})$ "Elephantskin" textures. (d) Putative macro-tufted microbial mat. (e-f) Clustered domal buildups and flat pyritized microbial structure (red arrow). Macrofossil specimens (white arrows). (g) Isolated domal buildups. (h) Wrinkle marks [Colour figure can be viewed at wileyonlinelibrary. com] 
(a)

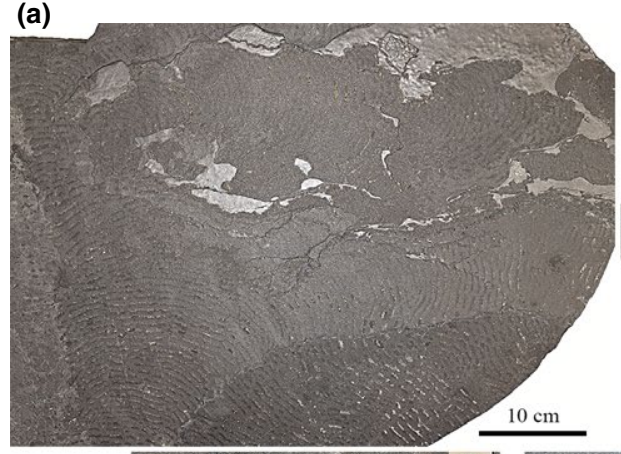

(b)
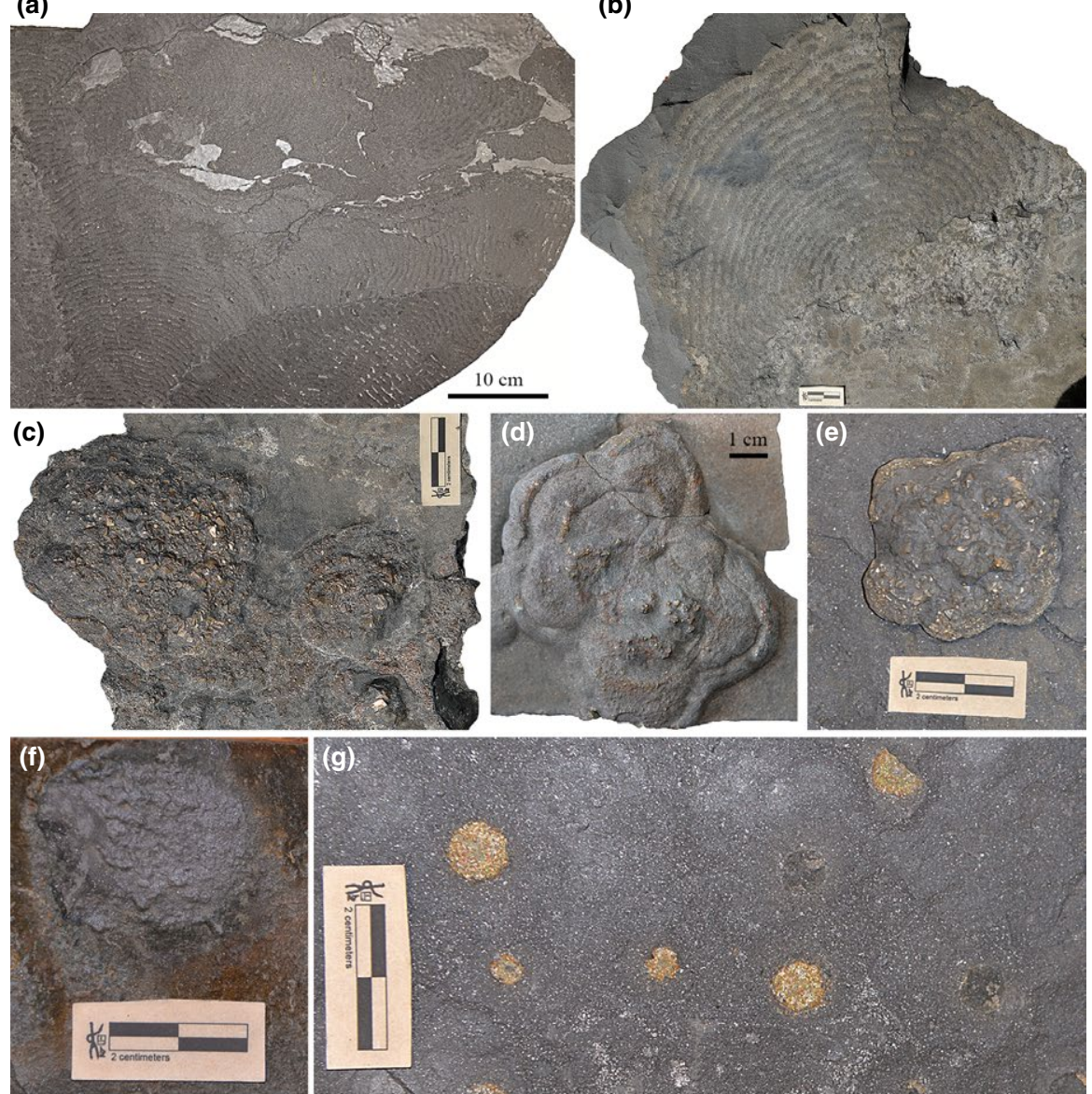

FIGURE 5 Microbial mat structures in the Francevillian B Formation (FB2): Mat-layer structures. (a,b) Discoidal mats likely representing "fairy ring" structures. (c-e) Disc-shaped mats that display a cauliflower-like pattern. (f) Disc-shaped mat with internal wrinkle structures. (g) Small pyritized circular bodies. (h) Horizontal mat growth pattern [Colour figure can be viewed at wileyonlinelibrary. com]

\subsection{1 | "Elephant-skin" textures}

\section{Description}

"Elephant-skin" textures (Runnegar \& Fedonkin, 1992) encompass quasi-polygonal, geometrically distinct reticulate patterns, ranging from the millimetre to centimetre scale, and bearing bulges or ridges (Figure $4 a-c)$. They are both identified at the top of the massive Poubara sandstones and the interbedded siltstones in the black shales (Figure 2). Individual polygons are $0.3-1.3 \mathrm{~cm}$ in diameter, with a maximum relief of $0.2 \mathrm{~cm}$.

Microscopic analyses show reticulate patterns preserved as nonhomogenous dark laminae above a light, coarser material 200-600 $\mu \mathrm{m}$ thick (Figure 7a,f). The overlying layer consists of abundant wavycrinkly laminae entangling 20-50 $\mu \mathrm{m}$ quartz grains and heavy minerals (e.g., titanium oxides, apatites and monazites); the latter suggested by the relative proportions of the elements found through SEM-EDS analysis (Figure S2), as well as transmitted and reflected light microscopy. Most of the grains in the wavy-crinkly laminae are randomly arranged within a clayey matrix and are dominated by $\mathrm{O}, \mathrm{Al}, \mathrm{Si}, \mathrm{Mg}, \mathrm{K}$ and Fe (Figure S2; Table S1). Reticulate patterns are also C-rich (up to 8.52\%) compared to the underlying sandstone bed, as evident from the Raman (Figure 8a-c) and organic elemental analyses (Table S2). The carbonaceous layer is punctuated by tufted microstructures, either on bulge rims or within the bulges, with similar striking morphologies to each other and where clay layers are almost vertically oriented (Figures $7 f$ and 9a,b). Based upon the description by Noffke, Christian, Wacey, and Hazen (2013), the height/base index is $30 / 100$ to $120 / 220 \mu \mathrm{m}$ long, separated at regular distances of $150-230 \mu \mathrm{m}$ from each other.

\section{Interpretation}

"Elephant-skin" textures are formed by a specific arrangement of tufts, pinnacles, bulges and smaller-scale bulges arranged into 
(a)
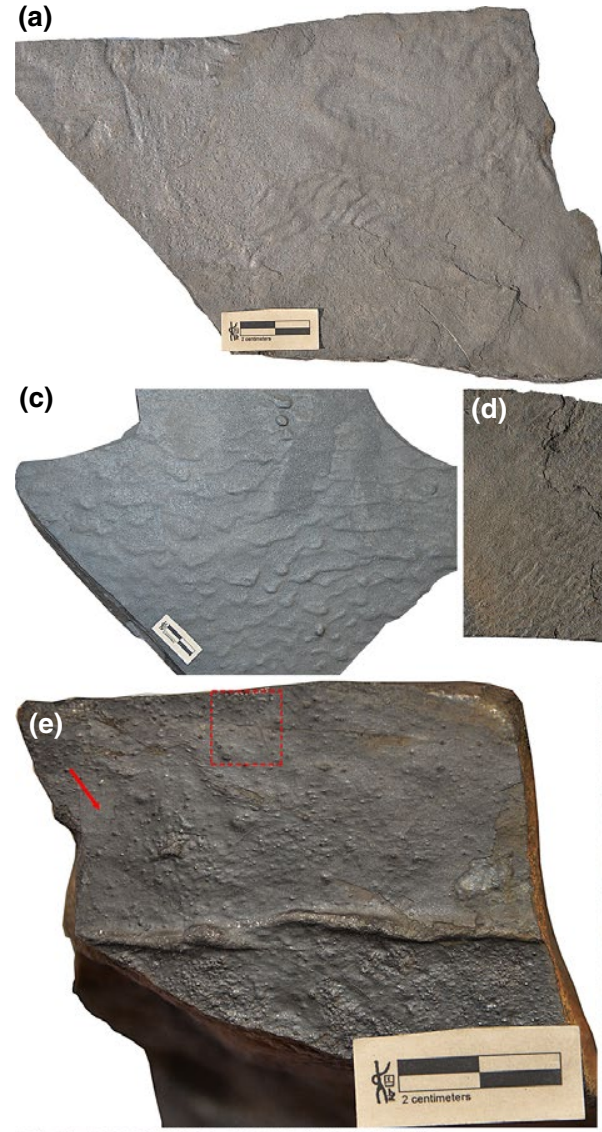

(g)

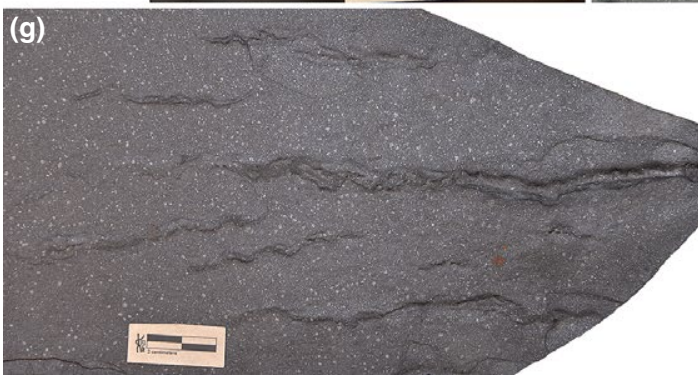

(d)
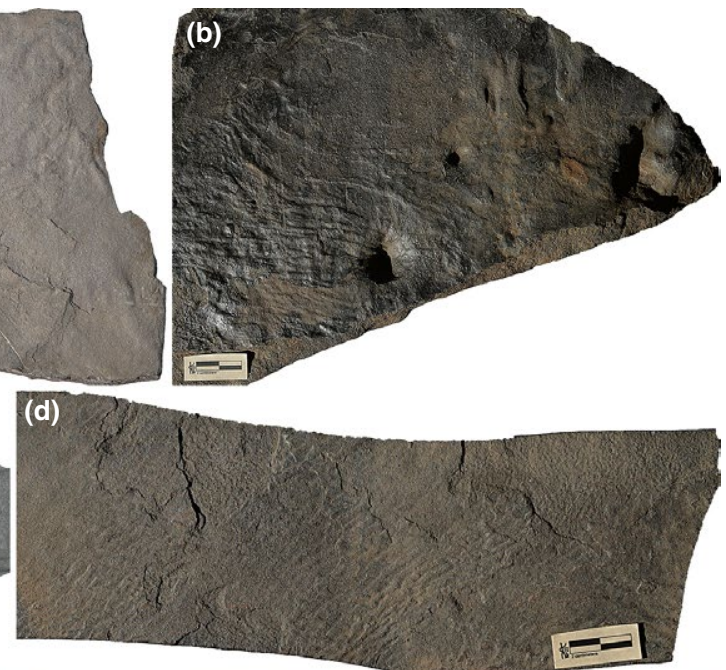

H
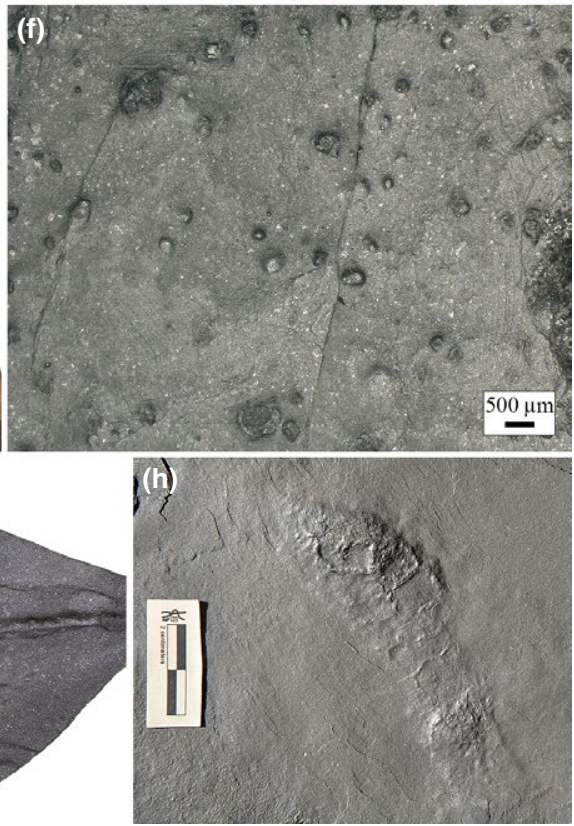

FIGURE 6 Mat-related structures in the Francevillian B Formation (FB2): Mat-protected structures. (a,b) Parallel wavy wrinkle structures. (c) Crosscutting wrinkle structures. (d) "Kinneyia" structure. (e) Linear pattern. Dashed red box indicates the position of the magnification in $\mathrm{f}$. Red arrow shows the location where the spectrometry Raman was performed. The Raman spectra are visible in Figure 8d. (f) Micrometric spots interpreting as oriented grains. (g) Linear patterns with several parallel ridges. (h) Nodular-like structure [Colour figure can be viewed at wileyonlinelibrary.com] ridges. Tufts, often arising in ridge junctions or at the intersection of microbial bulges, are proposed as a particular type-feature of cyanobacterial mat filaments growing vertically towards a light source (phototaxis; Bose \& Chafetz, 2009; Gerdes et al., 2000; Porada \& Bouougri, 2007). These textures are known in modern supratidal environments (Bose \& Chafetz, 2009; Gerdes, 2007; Gerdes et al., 2000; Taj, Aref, \& Schreiber, 2014), but have also been recorded and described in some ancient shallow water environments from the terminal Proterozoic (Gehling, 1999; Runnegar \& Fedonkin, 1992), and perhaps even the Archean (Flannery \& Walter, 2012). However, Shepard and Sumner (2010) debated the role of phototaxis in the formation of reticulate patterns and tufted structures. They investigated whether filamentous cyanobacteria were influenced by light to form polygonal structures or whether they were related to their own morphotype. Thus, reticulate patterns may result from an undirected motility of filamentous bacteria without the influence of light.

\subsection{2 | Putative macro-tufted microbial mat structures}

\section{Description}

The putative macro-tufted microbial mats are preserved as positive epireliefs that display patches of vertical bump-like structures protruding $0.05-0.2 \mathrm{~cm}$ on the upper surface of interbedded, coarsegrained siltstones (Figures 2 and $4 d$ ).

Microscopic features seen in longitudinal thin sections reveal that the coarse-grained siltstone is draped by a 50-500 $\mu \mathrm{m}$ thin, dark, clayrich layer with floating quartz grains (Figure $7 b, g, h)$. These grains are clearly different in size compared to the coarser grains in the underlying sediment. Some clay particles are micaceous and oriented more or less parallel to the bedding plane. Furthermore, it can be noted that the thickness of this overlying dark layer varies along the longitudinal section. The thinner dark-coloured layer is found at the top of the microtopography, whereas the thicker one overlies the troughs. 


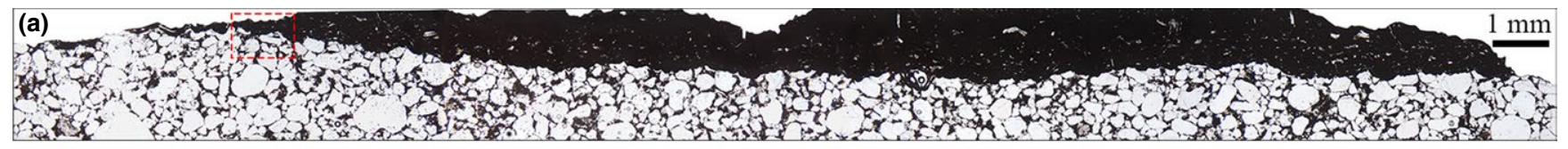

(b)

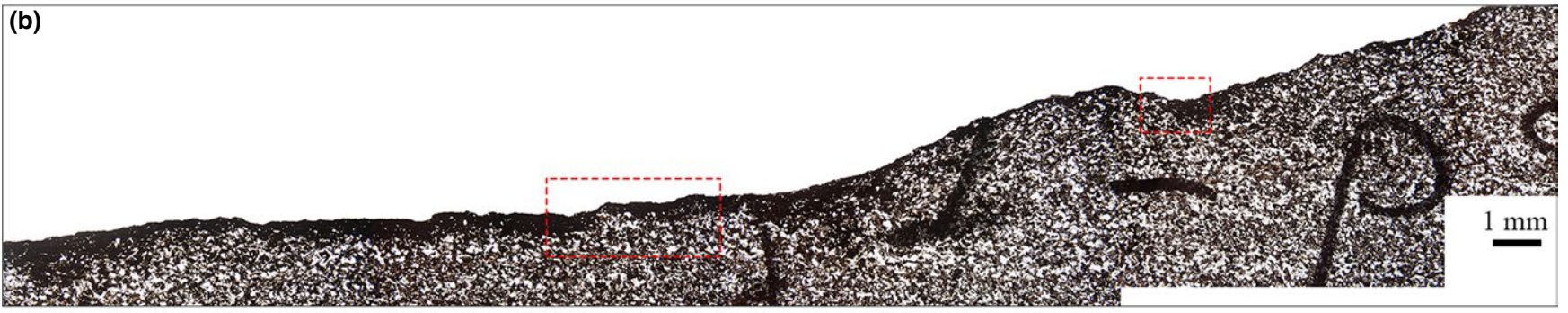

(c)
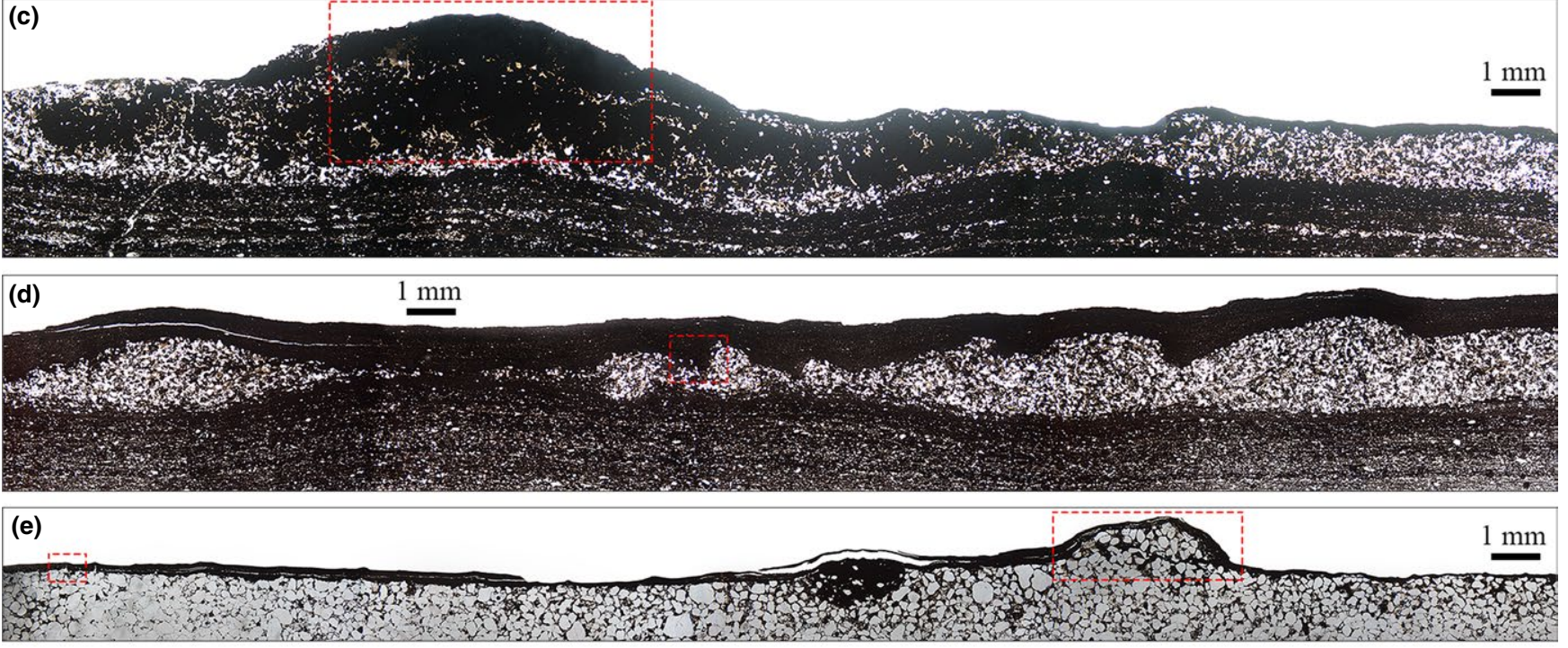

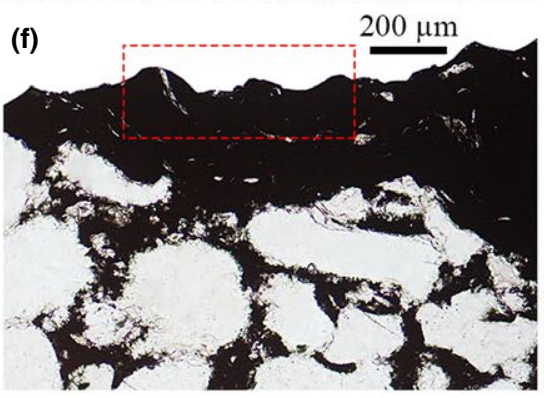

(i)

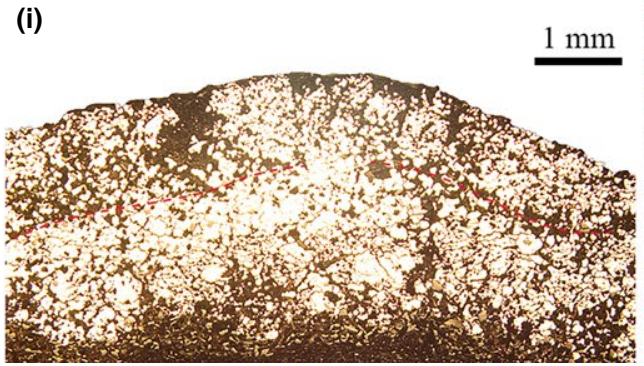

(g)

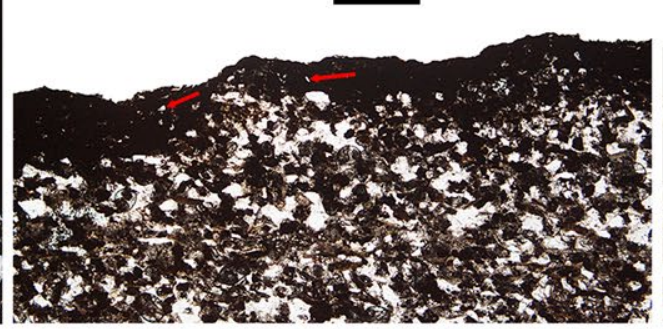

(i)

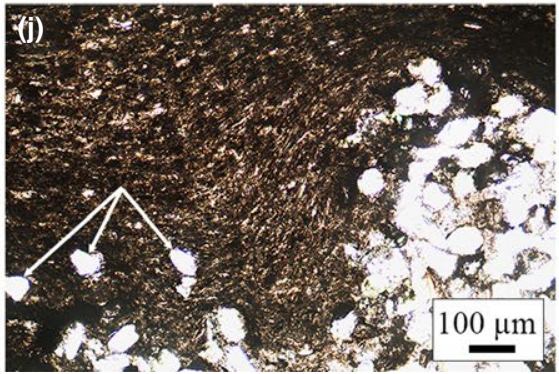

(h)

$200 \mu \mathrm{m}$

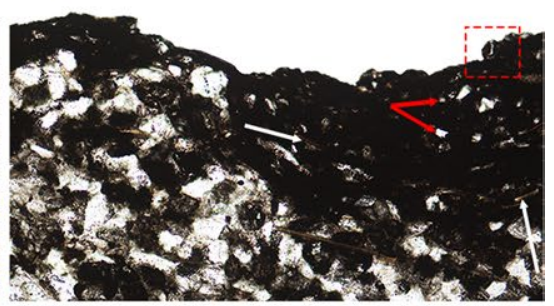

(k)

$100 \mu \mathrm{m}$

FIGURE 7 Optical photomicrographs of mat-related structures. (a) Transmitted thin section of "elephant-skin" texture. Dashed red box denoting area magnified in $\mathrm{f}$. (b) Transmitted thin section of putative macro-tufted microbial mat. Dashed red boxes denoting areas magnified in $\mathrm{g}$ and h. (c) Transmitted thin section of an isolated domal buildup. Dashed red box denoting area magnified in i. (d) Transmitted thin section of parallel wavy wrinkle structures. Dashed red box denoting area magnified in j. (e) Transmitted thin section of a linear pattern. Dashed red boxes denoting areas magnified in k and Figure 9e. (f) Tufted microstructures and wavy-crinkly laminae. Dashed red box denoting area magnified in Figure 9a. (g,h) Thickness variation across the mat layer with floating grains embedded by clays (red arrows). Mica (white arrows). Dashed red box denoting area magnified in Figure 9c. (i) Reflected magnified thin section of an entirely pyritized dome. An internal convex lamination is indicated by dashed red lines. (j) Clay laminae do not onlap the rippled siltstone bed but rather well follow its topography. Oriented grains (arrows). (k) High amount of quartz particles (arrows as example) within dark-coloured laminae. Dashed red box denoting area magnified in Figure $9 d$ [Colour figure can be viewed at wileyonlinelibrary.com] 
(a)
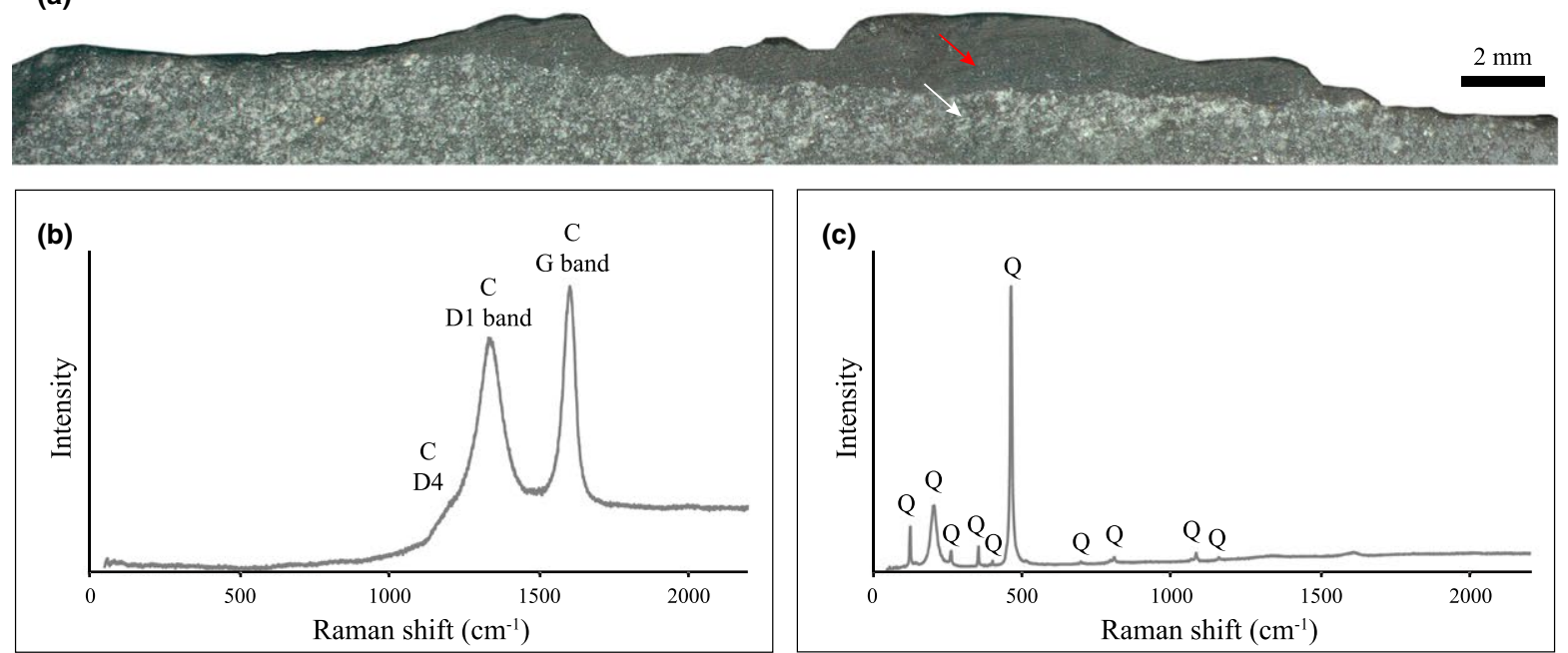

(c)
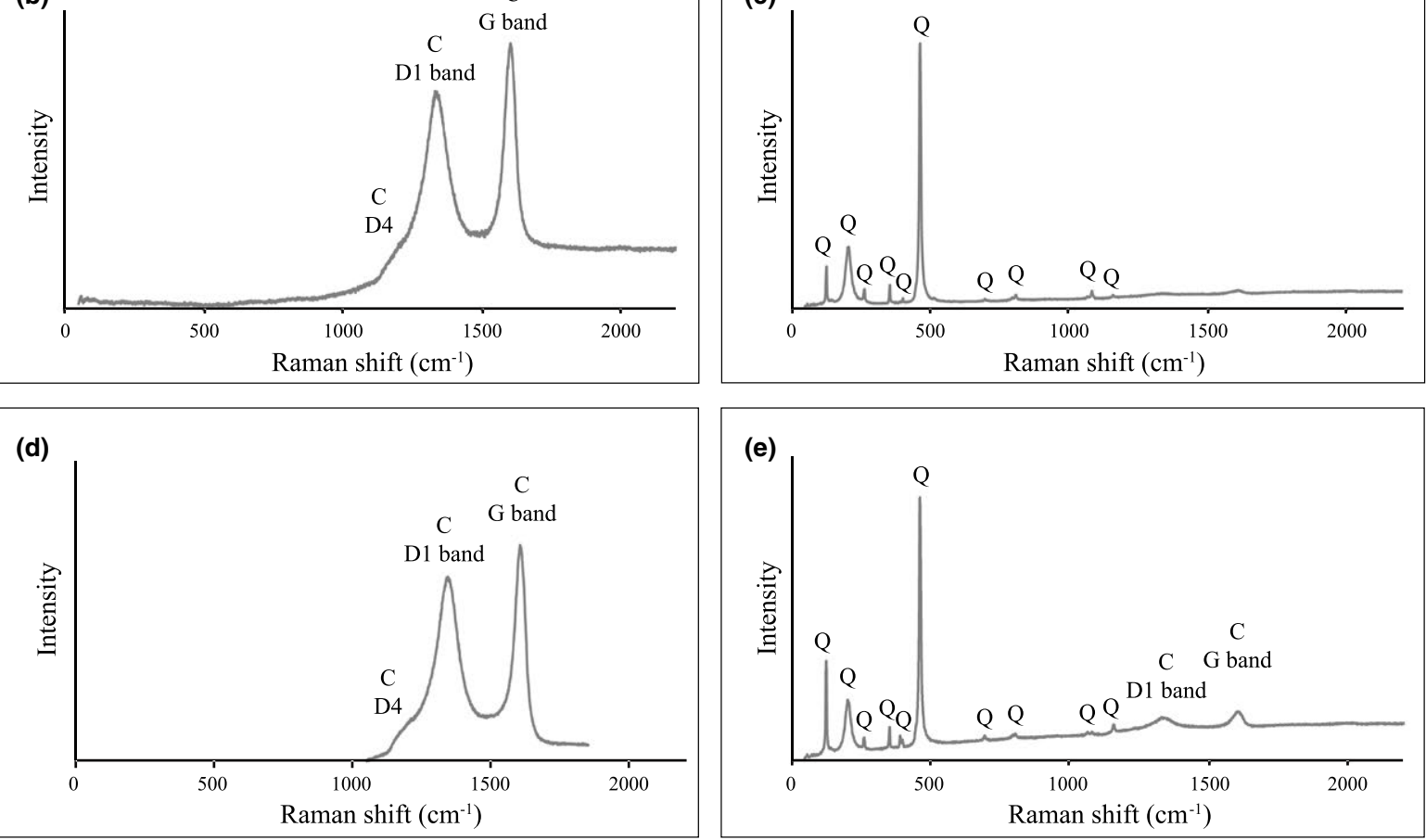

FIG URE 8 Polished slab of "elephant-skin" texture and Raman spectra of both "elephant-skin" texture and linear pattern. (a) Polished slab in cross-section perpendicular to bedding plane. Non-homogenous dark layer preserved above a pronounced boundary. Red arrow and white arrow indicate Raman spectra in b and c, respectively. (b) Representative Raman spectra of the microbial mat within bulges. It shows the presence of three carbon peaks ("C") at $1202 \mathrm{~cm}^{-1}$ ("D4" disordered peak), 1,336 cm-1 (the "D1" disordered peak) and 1,603 cm ${ }^{-1}$ (the "G" graphite peak). (c) Typical Raman spectra of sandstone with quartz ("Q") peaks. (d) Representative Raman spectra of mat layers of linear pattern indicated in Figure 6e. It shows the presence of three carbon peaks ("C") at $\sim 1,170 \mathrm{~cm}^{-1}$ ("D4" disordered peak), 1,344 cm ${ }^{-1}$ (the "D1" disordered peak) and 1,603 $\mathrm{cm}^{-1}$ (the "G" graphite peak). (e) Typical Raman spectra of host sediment of linear pattern, with quartz (Q) peaks and very small intensities of "C" peaks [Colour figure can be viewed at wileyonlinelibrary.com]

SEM imaging reveals that the dark lamina encompasses heterogeneously-sized, 5-40 $\mu \mathrm{m}$ quartz grains and heavy minerals (Figure 9c), while clay minerals are positioned subvertically. In addition, EDS analyses suggest that these laminated minerals are mainly made of $\mathrm{O}, \mathrm{Si}, \mathrm{Al}, \mathrm{K}$ elements, with minor $\mathrm{Mg}$, Fe and $\mathrm{Na}$ (Table S1), consistent with the elemental composition of mica and illite minerals (e.g., Velde \& Meunier, 2008).

\section{Interpretation}

A similar macro-tufted microbial mat was recorded from a $2.0 \mathrm{Ga}$ palaeodesert environment where $0.2 \mathrm{~cm}$ high mound-like structures are randomly arranged on a fine-grained sandstone (Simpson et al., 2013). The mechanism behind the development of this feature in the sedimentary rock record remains unclear. However, by changing the polarity of their filamentous structure, the growth of a microbial biofilm is able to produce similar bump-like structures in modern sedimentary environment (Bose \& Chafetz, 2009; Gerdes, 2007; Gerdes et al., 2000; Taj et al., 2014). This pattern may also result from the direct filling of the pre-existing microtopography by mat-building organisms as they grow and expand (Simpson et al., 2013). The smooth but bumpy morphology is likely enhanced by synsedimentary loading and post-depositional compaction, and so this bio-sedimentary expression could be viewed as a combined microbial and compaction feature.

\subsection{3 | Domal buildups}

\section{Description}

Domal buildups are preserved as positive bed-top features on bedding surfaces of black shales (Figure 2). They are characterized by $0.1-0.4 \mathrm{~cm}$ convex, domal structures projecting upwards from the bedding plane. Distinctive features include a cluster of low mound-shaped structures, $0.4 \mathrm{~cm}$ in diameter, nearly equal in all instances and without any central depressions (Figure 4e,f). In an alternative manner, they can be isolated structures with a diameter ranging from 0.7 to $1.5 \mathrm{~cm}$ that seem to reveal a cauliflower-like 

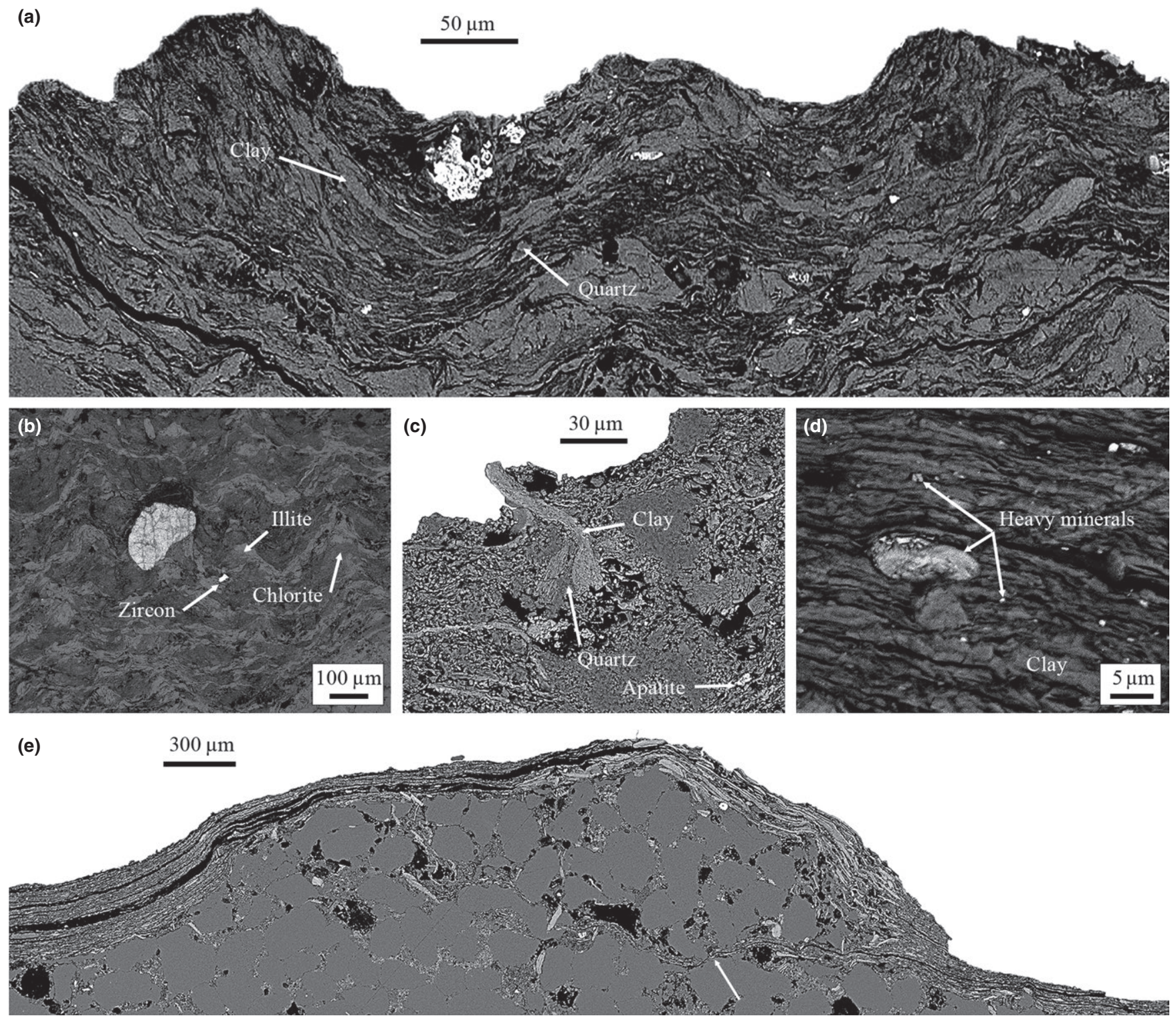

FIGURE 9 SEM imaging of mat-related structures. (a) Magnified view of box area in Figure 7f. Upward clay laminae within tufted microstructures and wavy-crinkly layers. (b). Tufted microstructures and heavy minerals constitute bulges of the "elephant-skin" texture. (c) Magnified view of box area in Figure 7h. Quartz grains, heavy minerals and randomly oriented clays constitute the dark-coloured mat layer. (d) Magnified view of box area in Figure 7k. Detrital particles wrapped by sheet clays. (e) Magnified view of box area in Figure 7e. Clay minerals above and throughout the ridge (arrow). No significant clue of liquefaction nor microbial shrinkage

texture associated with extensive positive relief, wrinkled structures (Figure 4g). Circular discs belonging to the oldest large colonial organisms (El Albani et al., 2014) seem closely associated with these specific structures. Both isolated and clustered domal structures have been shown to be pyritized (Table S2). Bulk sulphur level of up $22.16 \%$ within the domal structures is associated with a carbon content $<0.53 \%$. There are also flat, pyritized mat-related structures without any particular distinctive features that tend to develop close to the clustered domes (Figure 4f; Figure S1).

Thin sections reveal a well-defined alternation of clay and silt layers beneath the domal structures (Figure 7c). Most of the quartz particles from the underlying sediment are laminated and/or have a length of grain-to-grain contact of mostly $20-80 \mu \mathrm{m}$. None of these grains were found in the topmost dark, clay layer. Furthermore, the domal structures typically show an indication of internal convex lamination between all pyrite grains (Figure 7i), which reflects the position of the domes in epirelief.

\section{Interpretation}

Domal buildups have been reported from fluvial and fluviodeltaic settings in Mid-Proterozoic (Garlick, 1988; Schieber, 1998, 1999; Sheldon, 2012; Wilmeth, Dornbos, Isbell, \& Czaja, 2014) to shallow water settings in Late Cambrian times (Bottjer \& Hagadorn, 2007). The latter authors proposed that they "may represent different life histories, biological affinities, and/or histories of interaction with the physical environment". Previous studies have also invoked a distinct 
mat growth pattern (Wilmeth et al., 2014) and inferred that domal structures are built by an upward growth of microbial mats. This might reflects competition for light (Garlick, 1988; Schieber, 1999). The $\delta^{13} \mathrm{C}_{\text {org }}$ isotopic signatures of Mesoproterozoic domal-like structures in Copper Harbor Conglomerate (Upper Peninsula of Michigan) are attributed to photosynthesis (Sheldon, 2012).

Extracellular polymeric substances possess chemical properties that protect cells by creating sharp geochemical gradients (Decho, 2000), while the anaerobic decay of the buried mat material facilitates the precipitation of diagenetic minerals such as pyrite, depending on sulphate and iron bioavailability. If this diagenetic mineralization follows individual layers within the EPS demarcated boundaries, or if it is associated with specific features, the former presence of microbial mats are overprinted and preserved as a mineralized signature (Schieber, 1999). Thus, sulphate-reducing micro-organisms probably used the carbonaceous material from the domal buildups as their electron donor, thereby releasing hydrogen sulphide to react with available iron. This mechanism is supported by the recurrent low carbon to high sulphur contents in the materials. Analyses of the sulphur isotope contained in pyrite from the Francevillian series measured by Secondary Ion Mass Spectrometry (SIMS) further revealed negative $\delta^{34} S$ values associated with widespread microbial decay, linked to the activities of the sulphate-reducing micro-organisms (EI Albani et al., 2014).

\subsection{4 | Discoidal microbial colonies}

\section{Description}

A discoidal microbial colony (Grazhdankin \& Gerdes, 2007) is a term for a mat layer that includes disc-shaped, internal, centimetrescale features (Figure 5a-g). Two major distinct discoidal microbial colony-like morphologies occur on bedding planes in the black shale unit (Figure 2). The first is characterized by centimetre to the decimetre scale clusters of outward-convex, rod-shaped structures with internal pyritized concentric bands, possessing a series of $\sim 0.4 \mathrm{~cm}$ wide light and dark zones (Figure $5 \mathrm{a}, \mathrm{b}$ ). This specific feature does not exhibit any relief. The second variety is made up of well-marked circular bodies represented by sharp outlines separating the specimens from the surrounding black shale (Figure $5 \mathrm{c}-\mathrm{g}$ ). The disc-shaped colonies display slight internal concentric zonations, wrinkle features or a lack of any specific morphological characteristics. A variety of the specimens have a 1.1-1.7 cm high disc-shaped relief with concentric rims restricted to the edges, which may present themselves as cauliflower-like patterns varying between 3.3 and $8.2 \mathrm{~cm}$ in diameter (Figure $5 \mathrm{c}$ e). There are numerous distinct large euhedral pyrite crystals on these structures. Less common are disc-shaped bodies of $2.3 \mathrm{~cm}$ in diameter and represented by a minor relief, internal millimetrescale wrinkles, and devoid of sharp outlines (Figure 5f). Other observable discoidal structures are relatively small $(\sim 0.5 \mathrm{~cm}$ diameter) that do not have particular features (Figure $5 \mathrm{~g}$ ). However, these are the only structures that are entirely pyritized by tiny pyrite crystals.

\section{Interpretation}

Previous studies have shown that a wide range of variability exists in the morphology and organization of modern discoidal microbial colonies in natural environments (Banerjee, Sarkar, Eriksson, Hu, \& Wang, 2014; Gerdes et al., 1993; Sarkar et al., 2014) as well as under laboratory conditions (Matsushita et al., 2004). Concentric zonations with a series of light and dark bands represent a particular variety of discoidal microbial colony known as "fairy rings." Modern "fairy ring" structures are ubiquitous in salt marshes (Gerdes, 2007; Gerdes et al., 1993) and in shallow water environments (Banerjee et al., 2014). The concentric ring-shaped structures of the Francevillian series discoidal structures clearly display the same striking morphologies. All modern examples indicate that filamentous cyanobacteria and diatoms, which are embedded in EPS and crowned by micro-pinnacles, form these concentric ring-shaped structures. This arrangement is likely not random but represents an oriented behaviour that might be triggered by external environmental factors (Gerdes, 2007). So far, the generally accepted mechanism of formation involves escaping gas bubbles from the substrate, which may cause concentric wave propagation (Gerdes, Krumbein, \& Reineck, 1994). In a subsequent way, chemotactic responses initiated by adapted filamentous cyanobacteria may form the concentric organizational patterns. At present, the oldest discoidal microbial colonies that have been described are from Mesoproterozoic and Neoproterozoic shallow submarine environments (Banerjee, Sarkar, Eriksson, \& Samanta, 2010; Banerjee et al., 2014; Grazhdankin \& Gerdes, 2007; Sarkar et al., 2014), where pyritized filamentous structures are sometimes preserved (Grazhdankin \& Gerdes, 2007).

\subsection{5 | Horizontal mat growth pattern}

\section{Description}

A unique, outward-convex, spindle-shaped structure extending over $34 \mathrm{~cm}$ is developed on the bedding plane surface of the black shale unit (Figures 2 and $5 \mathrm{~h}$ ). The structure appears similar to the spindle-shaped "fairy ring" structures described above. However, this structure is represented by tiny, $0.1 \mathrm{~cm}$ tall, arched ridges, rising horizontally, following a well-defined geometric pattern. These sharp-crested ridges of $0.15 \mathrm{~cm}$ in width are regularly spaced, commonly dissected and slightly undulated. It appears that the laminae convexity of the whole structure is unevenly distributed, ranging from 55 to 86 degrees.

\section{Interpretation}

The horizontal mat growth pattern could be related to "fairy ring" structures with which the pattern shares some similarities (e.g., outward-convex, spindle-shaped, sharp-crested ridges). Nevertheless, there are no alternations of light and dark zones. Processes implicated in the formation of "fairy ring" structures may be involved here, but topography is added. The orientation of the wave propagation and subsequent millimetre-sized ripples may be induced by gravity. Then, pinnacle-forming organisms 
would interact with the nutrient front by chemotactic responses to colonize the substratum, producing the distinct morphology preserved in the sedimentary record. In an alternative way, localized mat failure and strain induced by gravity, waves or currents could also explain the morphology as a mechanical deformation of biogenically stabilized sediment. Although it has not been suggested in other studies, morphological features including a point of origin, persistent "growth" in one vector, and sharp boundaries could also be explained by an underwater seep that is confined by a biomat and promotes mat growth in a downslope direction. In any case, the parallel arrangement of ridges, as well as the regularity of components in the horizontal mat growth pattern, suggests a biotic origin.

\section{2 | Mat-protected structures}

This category of mat-related structures arises from structures that probably require mats for their preservation, the excepting being wrinkle marks.

\subsection{1 | Wrinkle structures}

\section{Description}

Based on morphology, three types of wrinkle structures are categorized here: wrinkle marks, parallel wavy wrinkle structures and cross-cutting wrinkle structures. Wrinkle marks are represented as laterally continuous or discontinuous, slight, outward-convex positive relief on bedding plane of the black shales (Figures 2 and 4h).

Parallel wavy wrinkle structures are preserved as sinuous, continuous ridges separated by parallel, narrow valleys extending for $<10 \mathrm{~cm}$ on bedding surfaces of sandstones and interbedded thin-to-medium-bedded siltstones (Figures 2 and $6 a, b$ ). The ridges have rounded tops and steep sides, with an individual ridge elevation of $0.1 \mathrm{~cm}$ and a spacing of $0.4 \mathrm{~cm}$. Organic elemental analysis of one sample from the black shale unit does not reveal significant differences in carbon content between the parallel wavy wrinkle structures and the surrounding sediment (Table S2). However, microscopic analysis of thin sections, cut perpendicularly through the wrinkles, indicates that a dark-coloured layer caps the coarse, silt-sized rippled structures. Further down, the sediment displays quasi-planar laminations (Figure 7d). For the length of the section, the topmost carbonaceous layer is similar in thickness and does not onlap the rippled bed, but instead reproduces its topography (Figure 7j). Oriented quartz grains trapped within the carbonaceous layer (Figure $7 \mathrm{j}$ ) appear to have the same grain size as those found in the rippled structure. Tiny floating grains are also embedded in the clay-sized fractions. Sheets of various clay particles entangle several heavy minerals, mainly titanium oxides (Table S1).

Cross-cutting wrinkle structures (Banerjee \& Jeevankumar, 2005) are characterized by bifurcating and frequently interconnected asymmetric ridges with intervening subparallel troughs on the bedding surface of black shales (Figures 2 and $6 \mathrm{c}$ ). The rounded ridges are $0.1-0.2 \mathrm{~cm}$ high, $0.4-0.5 \mathrm{~cm}$ wide, and their spacings vary from 0.4 to $1 \mathrm{~cm}$. A few dome-like structures of $0.5-0.6 \mathrm{~cm}$ are close to these cross-cutting wrinkle structures (Figure $6 \mathrm{c}$ ).

\section{Interpretation}

Wrinkle structures are one of the most common sedimentary features related to microbial mats. They are found over a large palaeogeographic range, including the deep-sea (Buatois \& Mángano, 2003; Flood, Bailey, \& Biddle, 2014), shallow marine (Banerjee \& Jeevankumar, 2005; Banerjee et al., 2014; Buatois, Narbonne, Mángano, Carmona, \& Myrow, 2014; Hagadorn \& Bottjer, 1997; Mata \& Bottjer, 2009; Porada \& Bouougri, 2007; Sarkar, Banerjee, Samanta, \& Jeevankumar, 2006; Sarkar, Choudhuri, Mandal, \& Eriksson, 2016; Sarkar et al., 2014; Yang, Chen, \& Fang, 2017), fluvial and lacustrine (Chu et al., 2015, 2017), and even continental environments (Simpson et al., 2013). Some researchers claimed that relative microbial community growth correlates to with irregular surface of wrinkle structures (Banerjee \& Jeevankumar, 2005; Hagadorn \& Bottjer, 1997; Sarkar et al., 2006, 2014).

Loading and dewatering processes have also been proposed for wrinkle generation (Noffke, Knoll, \& Grotzinger, 2002). A recent study has proposed that abiotic mechanisms are unable to create millimetre-scale ripples (3-15 $\mathrm{mm}$ wavelengths) because waves with small orbital amplitudes are not strong enough to mobilize sand and silt grains (Mariotti, Pruss, Perron, \& Bosak, 2014). In wave tank experiments, millimetre-scale ripples were perfectly reproduced by means of microbial aggregates rolling along the substrate and transporting grains. The preservation of such structures requires burial by fine material that may be represented by the biostabilization of a bacterial community. The dark-coloured layer overlapping the silt-sized rippled structures (Figure $7 \mathrm{~d}, \mathrm{j}$ ) is probably induced by EPS that acts as a trap for particles from the surrounding environment (Hagadorn \& Bottjer, 1997). Oriented grains are result of a growing biofilm that envelops, lifts, rotates and orientates the grains (Noffke, Gerdes, Klenke, \& Krumbein, 1997, 2001). By combining morphological description and petrographic study, it appears that wrinkle structures are polygenic. Both mat-layer and mat-protected structures are therefore most likely represented in this case.

\subsection{2 | "Kinneyia" structures}

\section{Description}

"Kinneyia" structures are characterized by clearly distinct, short, sinuous ridges and troughs of $0.2 \mathrm{~cm}$ in width and $<0.1 \mathrm{~cm}$ in height on the bedding surface of the black shale unit (Figures 2 and $6 \mathrm{~d}$ ). These structures fit with the definition of "Kinneyia" as proposed by (Porada, Ghergut, \& Bouougri, 2008), that is, they are "comparatively short, curved, frequently bifurcating, flat-topped crests, 0.5-1 $\mathrm{mm}$ high and 1-2 $\mathrm{mm}$ wide, which are separated by parallel, round-bottomed depressions. The crests are usually steep sided and may run parallel". 


\section{Interpretation}

The origins of "Kinneyia" structures have long been amongst the most problematic to understand. From their initial description as fossil algae (Walcott, 1914) to the present day where the term is now used to describe MRS, they have been interpreted in various ways (Hagadorn \& Bottjer, 1997; Mariotti et al., 2014; Noffke et al., 2002; Porada \& Bouougri, 2007; Porada et al., 2008; Thomas, Herminghaus, Porada, \& Goehring, 2013). However, few hypotheses properly explain how the underlying sediment is affected (Davies et al., 2016). Of late, "Kinneyia" structures were successfully reproduced in wave tank experiments using microbial aggregates (Mariotti et al., 2014), although the sharply defined morphology of the depressions preserved might suggest that gas bubbles formed beneath the biomat could also be a possible mechanism (Pfluger, 1999). It has also been demonstrated that "Kinneyia" is a polygenetic texture (Davies et al., 2016), but the Francevillian "Kinneyia" structures do not rule out formation by biotic mediators.

\subsection{3 | Linear patterns}

\section{Description}

Linear patterns are characterized by $0.1-0.3 \mathrm{~cm}$ high, parallel, linear ridges, slightly undulated on the bedding surfaces of massive sandstones and interbedded siltstones (Figures 2 and 6e,g). They are of varying size, ranging from 2 to $8 \mathrm{~cm}$ in length and $0.3-0.7 \mathrm{~cm}$ in width. Around these linear ridges, the surface morphology is not uniformly flat but bears micrometric spots that seem to be embedded in the matrix (Figure 6f). Furthermore, Raman spectrometry indicates this dark-coloured layer is carbon-rich compared to the underlying sediments (Figure 8d,e).

Microscopic observations reveal that the $100-300 \mu \mathrm{m}$ thick, carbon-rich layer lies on lighter, sand-sized quartz grains and consists of multiple, well-defined sheets of clay minerals (Figure 7e,k). SEM imaging shows that numerous small quartz grains and heavy minerals, such as apatite, titanium oxide and zircon, are embedded in the clay matrix (Figure 9d,e). This matrix is formed by $\mathrm{O}, \mathrm{Si}, \mathrm{Al}$, $\mathrm{Mg}$, Fe and $\mathrm{K}$ elements, that is chlorite and illite, as expressed by EDS analyses (Table S1). Furthermore, sand-sized quartz grains are observed inside the ridges as well as the surrounding sediment but are separated by a clayish undulated layer (Figure 9e). The quartz grains inside the ridges and those from the host rock appear randomly oriented.

\section{Interpretation}

According to the identification of linear patterns in modern tidal flats by (Porada \& Bouougri, 2007) "straight to irregular ridges are developed at distance of 1-2 cm and are locally interrupted or reduced to faint lines on the flat mat surface". Towards the water line, oriented bacterial filaments dominate these structures. In experimental studies, Shepard and Sumner (2010) observed linear ridges of up to $15 \mathrm{~cm}$ long made of cyanobacterial filaments running parallel to the incident light. Moreover, it has been proposed that a faint rippled surface may imply a linear pattern because of the preferential microbial growth following slight ridges (Bouougri \& Porada, 2007; Gerdes, 2007; Porada \& Bouougri, 2007).

The presence of carbonaceous material within the dark-coloured layer is congruent with a biotic origin. Microtextures, such as tiny quartz particles and heavy minerals embedded in the matrix, are caused by the trapping and binding processes related to microbial activity (Gerdes, 2007; Noffke, 2010). Individual grains bound in the organic matrix can be compared to those observed with laboratorygrown cyanobacteria. These are described as oriented grains that are pushed upwards during their growths (Noffke, 2010; Noffke et al., 2001).

On a macroscopic level, the Francevillian MRS strongly resemble the linear structures described above, commonly equivalent in shape but slightly smaller in size. However, no microscopic features were described until now. Taking microtextures into account, it seems unlikely that bacterial orientation is capable of mobilizing large amount of sediments to form ridges. Microbial shrinkage caused by a period of subaerial exposition, is also a possibility (e.g., Chu et al., 2017; Kovalchuk, Owttrim, Konhauser, \& Gingras, 2017), although the surface morphologies and microtextures are not consistent with this process. Also, dilational strain on a mildly dipping sediment surface could explain these features, but their orientations are irregular and their distributions are sporadic. Liquefaction underneath the microbial mat, due to a rise in pressure (e.g., Porada, Bouougri, \& Ghergut, 2007), could have been the cause of these particular ridges but neither sediment rising nor upward-facing microbial laminae beneath the ridges have been observed. At last, linear patterns may result from two growth periods interrupted by small and rippled sedimentary structures (Figure 9e). This condition might be the best explanation for microbial laminae throughout the linear ridges, and the second mat growth period may have followed the ridge orientation as previously thought (Bouougri \& Porada, 2007; Gerdes, 2007; Porada \& Bouougri, 2007). In some way, linear patterns are considered to be mat-protected structures.

\subsubsection{Nodule-like structures}

\section{Description}

Nodule-like structures are characterized by an elongated shape approximately $10 \mathrm{~cm}$ long and an irregular surface topography on the bedding surfaces of black shales (Figures 2 and $6 \mathrm{~h}$ ). The surfaces of nodule-like structures comprise several millimetre-scale, tiny, crinkled ridges that are randomly distributed. Composed of silt-sized grains and capped by a dark-coloured wrinkle layer, the nodule-like structure was observed in a polished slab.

\section{Interpretation}

Similar nodular to biscuit-like surface structures have been observed in laboratory-cultured bacteria and in modern supratidal settings (Gerdes, 2007). This atypical morphology is thought to be produced by a relative abundance of coccoid cyanobacteria. However, the Francevillian nodular structures possibly reflect mat-protected 
TAB LE $1 \delta^{13} \mathrm{C}$ values of organic matter in mat-related structures (MRS)

\begin{tabular}{lll} 
Subunits & Samples & $\boldsymbol{\delta}^{13} \mathbf{C}_{\text {org }}(\%)$ \\
\hline FB2b & MRS_1 & -34.92 \\
Black shale & MRS_2 & -34.41 \\
FB2a & MRS_3 & -32.45 \\
Sandstone & MRS_4 & -41.26 \\
& MRS_5 & -31.68 \\
& MRS_6-1 & -32.72 \\
& MRS_6-2 & -33.32 \\
& MRS_7 & -33.95 \\
& MRS_8 & -33.55 \\
& MRS_9 & -33.66 \\
& MRS_10 & -33.61 \\
MRS_11 & -32.28 \\
MRS_12 & -30.67 \\
MRS_13 & -31.95 \\
MRS_14 & -32.03 \\
\hline
\end{tabular}

structures instead of mat growth structures since the internal part of the nodules is not composed of organic matter but rather of quartz particles.

\section{3 | Isotopic analyses}

The $\delta^{13} \mathrm{C}$ values (V-PDB) of the organic fraction, measured on different mat morphologies in both sandstone and black shale facies range from $-30.67 \%$ o to $-41.26 \%$ (Table 1 ). These values are similar to previous determinations on the bulk $\delta^{13} \mathrm{C}$ of the organic matter within the FB2 sequence, varying between ca. $-35 \%$ and $-30 \%$ (Canfield et al., 2013; Gauthier-Lafaye \& Weber, 2003).

\section{6 | DISCUSSION}

\section{1 | Biogenicity}

The biogenicity criteria reviewed in Noffke (2009) and Wacey (2009) establishes the investigated mat-like structures to be of a microbial mat origin, having formed on the shallow marginal self-environment of the $2.1 \mathrm{Ga}$ Francevillian basin (Reynaud et al., 2017). The sedimentary facies on which the structures are identified must not have undergone metamorphism beyond greenschist grade (Noffke, 2009). This is in agreement with the absence of metamorphic overprint in the Francevillian facies (maximum temperature $100^{\circ} \mathrm{C}$; Gauthier-Lafaye \& Weber, 1989; Ngombi-Pemba et al., 2014). In terms of shape and size, the Francevillian MRS are a perfect match to those described in the Precambrian and the Phanerozoic (Figures S3 and S4) in accordance with the size distribution between modern and ancient MRS, which should be comparable (Noffke, 2009). In general, the taphonomic preservation window of MRS in the sedimentary record is valid, but not restricted by ecological setting (Davies et al., 2016). Noffke (2009) suggested that most MRS are related to photoautotrophic mats formed in well-lit shallow marine environments, preferentially on fine sand deposits, even though recent studies argued that such features can also arise on deep marine sediments that do not receive light (Davies et al., 2016). Regardless, our samples originated from a shallow marine setting associated with rapid sand flow deposits within a well-lit portion of the $2.1 \mathrm{Ga}$ Francevillian continental shelf (Reynaud et al., 2017).

Microtextural composition of the analysed fabric further supports the biological trapping, binding (or "flypaper" effect) and orientation of grains induced by the growth and development of microbial mats and their hydrologically-controlled interaction with sediments. The Francevillian MRS express this biological process by containing clay particles, floating grains of silt-sized quartz and concentrated heavy minerals, as well as by wavy-crinkly laminae (Figures $7 f-k$ and 9; Figure S2, Table S1). These form well-defined organo-sedimentary structures caused by microbial baffling and trapping. The randomly oriented clay minerals in mat laminae suggest that they were trapped on the mat surface whereas laminated clay particles suggest a probable alignment by compaction (Schieber, 1998). Oriented grains reflect a particular microtexture (Figures $6 \mathrm{f}$ and $7 \mathrm{j}$ ), while grain size matches that of the underlying substratum. It is commonly thought that these particles were dragged upwards by cyanobacterial mat growth (Noffke et al., 1997, 2001).

In addition, geochemical evidence suggests bacterially induced biological processes characterized by carbonaceous material enriched in light carbon (Figure 8; Table 1) and pyritized structures (Figures $4 \mathrm{e}-\mathrm{g}, 5 \mathrm{a}-\mathrm{e}, \mathrm{g}, 7 \mathrm{c}, \mathrm{i}$ ) that are depleted in heavy sulphur. The latter points to diagenetic mat destruction through burial decay (Noffke, 2009; Noffke et al., 2013) and anaerobic respiration of that organic carbon by sulphate-reducing micro-organisms (El Albani et al., 2014; Hill, Corcoran, Aranha, \& Longstaffe, 2016).

\subsection{Palaeoenvironmental interpretations and implications}

Modern mat-related structures are mostly described in carbonate and siliciclastic environments but few have been described from shale deposits. The presence of black shales with large amounts of organic matter deposited in the photic zone may arise in restricted to isolated basins (Schwark \& Frimmel, 2004). Some anoxygenic photosynthetic bacteria even prospered in these palaeoecological conditions and their high productivity may be related to the availability of essential nutrients. For any MRS-bearing rocks, the hydraulic pattern must be moderated with a low sedimentation rate to promote the development of microbial communities on a substrate (Gerdes, 2007; Gerdes et al., 2000; Noffke, 2009, 2010; Schieber, 1999). As an indicator of palaeo-hydrological conditions, clay minerals and silt-sized grains within mat layers, are taken to represent currents strong enough to move thin particles but insufficient to transport sand-sized grains (Noffke, 2009; Schieber, 1998). Silt-sized sedimentary particles and heavy minerals can also be baffled and trapped 
by cyanobacterial filaments moving vertically upwards in order to escape being buried by the small-sized particles, as well as their need to reach optimal light conditions for growth (Noffke, 2009, 2010).

In this study, some of the mat-like structures, including the "elephant-skin" morphotypes, the tufted structures, and the linear patterns, tend to be associated with silty lenses (Figure 2), suggesting that the baffling and grain trapping processes were operating in potential microbial mat-dominated environments at $2.1 \mathrm{Ga}$. Further, the comparable association of several MRS to the distribution of modern and fossil analogues have been used to improve the reliability of palaeoenvironmental marine interpretations, including physical processes such as desiccation and erosion and biological activity (Banerjee et al., 2014; Bose \& Chafetz, 2009; Noffke et al., 2013; Sarkar et al., 2014). It is important that, the absence of desiccation and erosion-induced MRS in the Francevillian rocks suggest a quiet underwater environment from the time of deposition to when the sediments were lithified and buried.

The Paleoproterozoic Francevillian MRS possess a wide spectrum of morphologies that can be related to photoautotrophic microbial assemblages. Indeed, discoidal microbial colonies in the modern environments and domal buildups in ancient settings are results of cyanobacterial chemotaxis or phototaxis behaviours (Gerdes, 2007). The biological mechanisms leading to oriented grains has been reproduced with cultures of cyanobacteria (Noffke et al., 2001). Reticulate patterns and tufted microbial mats have striking morphologies with modern analogues built by filamentous cyanobacteria (Figure S3a; Gerdes et al., 2000; Gerdes, 2007; Bose \& Chafetz, 2009; Taj et al., 2014). It is thought that their formation implies a phototactic behaviour (Gerdes et al., 2000; Reyes et al., 2013), whereas laboratorycultured filamentous cyanobacteria show a dependency on oxygen concentration (Sim et al., 2012). It has also been proposed that the undirected gliding motility of filamentous bacteria species may form these structures (Shepard \& Sumner, 2010). Therefore, all bacteria with highly motile filaments are believed to be able to display these morphologies. Filamentous sulphur-oxidizing bacteria may also have the ability to produce "elephant-skin"-like and tuft-like structures (Flood et al., 2014). However, research by genomic comparisons reveals that these phenotypic traits were most likely inherited by horizontal gene transfers from the cyanobacteria (Flood et al., 2014). In other words, those aerobic chemolithoautotrophs may not have been in existence at $2.1 \mathrm{Ga}$. In addition, recent studies in a perennially ice-covered Antarctic lake have shown the specific assemblage of a photosynthetic microbial ecosystem (Jungblut et al., 2016; Sumner, Hawes, Mackey, Jungblut, \& Doran, 2015), with cyanobacteria forming tuft-related structures exclusively found in the oxic zone where irradiance is at its highest, whereas flat bacterial mats of anoxygenic photoautotrophs are restricted to the deeper euxinic zone experiencing lower irradiance. Thus, "elephant-skin" and tufted structures may possibly have a link with oxygenic photoautotrophic micro-organisms. It is important that, Flannery and Walter (2012)

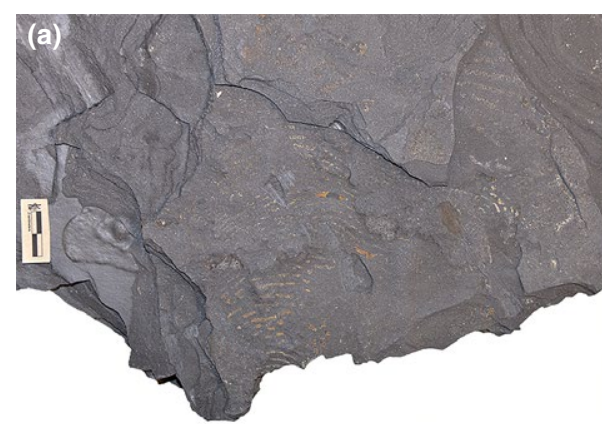

(b)
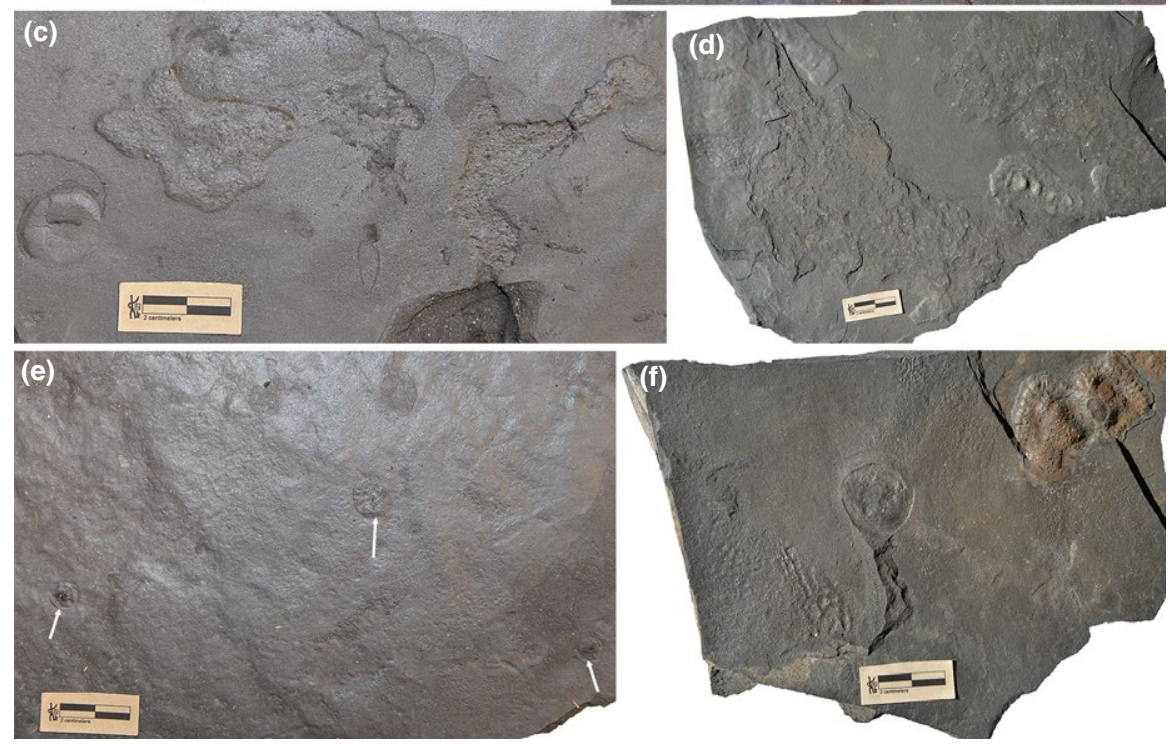

FIGURE 10 Examples of fossil macroorganisms associated with microbial mats. (a) Pyritized lobate form just beneath "fairy ring" structures. (b) Disc with radially striated core (arrow) lies on domal buildups. (c,d) Disc or lobate form and flat pyritized microbial structures on the same strata are closely associated. (e) Circular discs (arrows) rest on wrinkle marks. (f) Disc and lobate form are close to wrinkle marks on the same level or not [Colour figure can be viewed at wileyonlinelibrary.com] 
and Homann, Heubeck, Airo, and Tice (2015) thought that cyanobacteria are the only micro-organisms capable of producing vertical structures or tufts.

\section{3 | Geomicrobiological implications}

It is well established that carbon fixation by autotrophic organisms preferentially incorporates light ${ }^{12} \mathrm{C}$ over heavy ${ }^{13} \mathrm{C}$ isotopes in biomass (Schidlowski, 1988, 2001). In this regard, the $\delta^{13} \mathrm{C}_{\text {org }}$ values ranging from $-30.67 \%$ o to $-41.26 \%$ o (average $-32.94 \pm 1.17 \%$ o) reported here are within the expected range for autotrophic carbon fixation (Berg et al., 2010; Schidlowski, 1988, 2001). The typical $\delta^{13} C_{\text {org }}$ values generated by the widespread activity of ribulose 1,5-bisphosphate carboxylase/oxygenase (RuBisCo), common in oxyphototrophic cyanobacteria have average values from $-20 \%$ to $-30 \%$. These values are less negatively fractionated than anoxygenic phototrophs (Berg et al., 2010; McNevin et al., 2007; Quandt, Gottschalk, Ziegler, \& Stichler, 1977), while more negative values $<-30 \%$ are related to autotrophic carbon fixation in the reductive acetyl CoA pathway (i.e., methanogenesis). In the case of the latter, acetoclastic methanogenesis diagenetically supplies isotopically light ${ }^{12} \mathrm{C}$ methane to anaerobic oxidation of methane (AOM), the latter often comprising a consortia of sulphate reducers and methanotrophs (Conrad, Claus, \& Casperb, 2010). Therefore, autotrophic carbon fixation via acetyl CoA pathway, combined with anaerobic oxidation of fixed $\mathrm{C}_{\text {org }}$, would effectively lead to deposition of residual $\mathrm{C}_{\text {org }}$ enriched in light ${ }^{12} \mathrm{C}$ in the range found in this study. Such fixation of $\mathrm{CO}_{2}$ coupled with diagenetic recycling of phototrophically derived $C_{\text {org }}$ would have inevitably resulted in the sequential overprinting of light $\delta^{13} \mathrm{C}$ in buried biomats. The bulk $\delta^{13} \mathrm{C}_{\text {org }}$ signatures $<-30 \%$ are, therefore, most parsimoniously interpreted to represent a mixed isotopic signal resulting from the activities of various primary producers and heterotrophs.

The FB2b subunit hosts the first known multicellular organisms closely associated with biomats (Figures 2 and 10). Burrows, trails and resting traces of metazoans are often closely associated with biomats in the past, being interpreted as sophisticated feeding behaviours (e.g., Buatois \& Mángano, 2012; Buatois et al., 2014; Chu et al., 2015; Meyer et al., 2014; Pecoits et al., 2012). In modern environments, photosynthetic bacterial mats create thin $\mathrm{O}_{2}$-rich layers, thus providing benthic $\mathrm{O}_{2}$ oases for macroorganisms that may mine mat layers for unexploited nutrients and $\mathrm{O}_{2}$ (Gingras et al., 2011). It is perhaps not a coincidence then that the biomats and macroorganisms belong to the same strata. Moreover, the generation of microenvironments due to the chemical properties of EPS (Decho, 2000) may permit soft-tissue mineralization, providing further protection against degradation (Sagemann, Bale, Briggs, \& Parkes, 1999). Thus, the biomats may have stabilized the depositional surfaces and sheltered the macroorganisms, allowing them to become imprinted into the rock record. In an interesting way, the large colonial organisms associated with bacterial communities are only known from the FB2b rocks. Although other black shale facies are recorded in the Francevillian basin (e.g., the $\sim 2.08 \mathrm{Ga}$ FD black shale formation; Figure $1 \mathrm{~b}$ ), they were deposited in deeper environments beyond the euphotic zone (Canfield et al., 2013).

\section{7 | CONCLUSION}

Mat-related structures of the $2.1 \mathrm{Ga}$ Francevillian series exhibit ten types of surface morphologies, providing a new window into the highly diversified Paleoproterozoic microbial life at that time. Mats are preserved in excellent conservation conditions from a $20 \mathrm{~m}$ thick interval of sandstone and black shale facies.

Microtexture analyses provide strong evidence in favour of matcolonized sediment. Oriented grains, floating grains, heavy mineral concentrations, randomly oriented clays, pyritized structures and wavy-crinkly laminae all reflect the growth of microbial communities. Comparisons with ancient and modern analogues, as well as stable carbon isotope analyses, suggest growth within a palaeoenvironmental settings corresponding to the euphotic zone, likely $<100 \mathrm{~m}$ deep. Associations between Paleoproterozoic, large colonial organisms and mats may be similar to interactions of Ediacaran early metazoans and microbial carpets where $\mathrm{O}_{2}$-producing cyanobacterial mats may explain this specific pattern. In addition, microbial mats may have played a major role in sediment biostabilization, fostering the preservation of complex macroorganisms that represent the first ecosystem comprising microbial biofilms and large colonial life forms.

\section{ACKNOWLEDGMENTS}

We thank the Gabonese government; National Center for Scientific Research of Gabon (CENAREST); Sylvia Bongo Foundation; Agence Nationale des Parcs Nationaux of Gabon for logistic supports; University of Masuku; French Embassy at Libreville; and Institut Français du Gabon, French Ministry for Foreign Affairs. We are grateful to Prof. P. Mouguiama Daouda for his support. ECF is funded by the European Research Council (ERC) Seventh Framework Program (FP7) grant No. 336092. Funding for KK and MG were provided by the Natural Sciences and Engineering Research Council (NSERC). For information and scientific discussion, we acknowledge O. Bankole, C. Fontaine and J-Y. Reynaud. For assistance, we thank N. Guignard (Raman microprobe analysis) and J. Laduranty (CHNS analysis). In France, we are grateful to the French CNRS, FEDER, the Universities of Poitiers and Lille 1, and the Nouvelle Aquitaine Region. All coauthors agree to the publication of this manuscript and declare no conflict of interest.

\section{ORCID}

Abderrazak El Albani (iD http://orcid.org/0000-0001-9598-955X 


\section{REFERENCES}

Azziley Azzibrouck, G. (1986). Sédimentologie et géochimie du Francevillien $B$ (Protérozoïque inférieur). Métallogénie des gisements de manganèse de Mouanda, Gabon.

Banerjee, S., \& Jeevankumar, S. (2005). Microbially originated wrinkle structures on sandstone and their stratigraphic context: Palaeoproterozoic Koldaha Shale, central India. Sedimentary Geology, 176, 211-224. https://doi.org/10.1016/j.sedgeo.2004.12.013

Banerjee, S., Sarkar, S., Eriksson, P. G., Hu, X.-F., \& Wang, Y. (2014). Palaeoenvironmental and biostratigraphic implications of microbial mat-related structures: Examples from the modern Gulf of Cambay and the Precambrian Vindhyan Basin, India. Journal of Palaeogeography, 3, 127-144.

Banerjee, S., Sarkar, S., Eriksson, P. G., \& Samanta, P. (2010). Microbially related structures in siliciclastic sediment resembling Ediacaran fossils: Examples from India, ancient and modern. In J. Seckbach, \& A. Oren (Eds.), Microbial mats: Modern and ancient microorganisms in stratified systems (pp. 109-129). Dordrecht, the Netherlands: Springer. https://doi.org/10.1007/978-90-481-3799-2

Bankole, O. M., El Albani, A., Meunier, A., Rouxel, O. J., Gauthier-Lafaye, F., \& Bekker, A. (2016). Origin of red beds in the Paleoproterozoic Franceville Basin, Gabon, and implications for sandstone-hosted uranium mineralization. American Journal of Science, 316, 839-872. https://doi.org/10.2475/09.2016.02

Bekker, A., \& Holland, H. D. (2012). Oxygen overshoot and recovery during the early Paleoproterozoic. Earth and Planetary Science Letters, 317-318, 295-304. https://doi.org/10.1016/j.epsl.2011.12.012

Bekker, A., Holland, H. D., Wang, P.-L., Rumble, D., Stein, H. J., Hannah, J. L., ... Beukes, N. J. (2004). Dating the rise of atmospheric oxygen. Nature, 427, 117-120. https://doi.org/10.1038/nature02260

Berg, I. A., Kockelkorn, D., Ramos-Vera, W. H., Say, R. F., Zarzycki, J., Hügler, M., ... Fuchs, G. (2010). Autotrophic carbon fixation in archaea. Nature Reviews Microbiology, 8, 447-460. https://doi. org/10.1038/nrmicro2365

Berner, R. A. (2004). The Phanerozoic carbon cycle: $\mathrm{CO}_{2}$ and $\mathrm{O}_{2}$. Oxford, UK: Oxford University Press.

Bertrand-Sarfati, J., \& Potin, B. (1994). Microfossiliferous cherty stromatolites in the 2000 Ma Franceville group, Gabon. Precambrian Research, 65, 341-356. https://doi.org/10.1016/0301-9268(94)90112-0

Bonhomme, M. G., Gauthier-Lafaye, F., \& Weber, F. (1982). An example of lower proterozoic sediments: The Francevillian in Gabon. Precambrian Research, 18, 87-102. https://doi. org/10.1016/0301-9268(82)90038-9

Bose, S., \& Chafetz, H. S. (2009). Topographic control on distribution of modern microbially induced sedimentary structures (MISS): A case study from Texas coast. Sedimentary Geology, 213, 136-149. https:// doi.org/10.1016/j.sedgeo.2008.11.009

Bottjer, D. J., \& Hagadorn, J. W. (2007). Mat-growth features. In J. Schieber, P. K. Bose, P. G. Eriksson, S. Banerjee, S. Sarkar, W. Altermann, \& O. Catuneanu (Eds.), Atlas of microbial mat features preserved within the siliciclastic rock record (pp. 53-71). Amsterdam, the Netherlands: Elsevier.

Bouougri, E. H., \& Porada, H. (2007). Mat-related features from the terminal Ediacaran Nudaus Formation, Nama Group, Namibia. In J. Schieber, P. K. Bose, P. G. Eriksson, S. Banerjee, S. Sarkar, W. Altermann, \& O. Catuneanu (Eds.), Atlas of microbial mat features preserved within the siliciclastic rock record (pp. 214-222). Amsterdam, the Netherlands: Elsevier.

Bouton, P., Thiéblemont, D., Gouin, J., Cocherie, A., Guerrot, C., Tegyey, M., ... Moussavou, M. (2009). Notice explicative de la Carte géologique de la République du Gabon à 1/200 000, feuille Franceville-Boumango. Libreville, 79 p.

Bros, R., Stille, P., Gauthier-Lafaye, F., Weber, F., \& Clauer, N. (1992). Sm-Nd isotopic dating of Proterozoic clay material: An example from the Francevillian sedimentary series, Gabon. Earth and Planetary Science Letters, 113, 207-218. https://doi. org/10.1016/0012-821X(92)90220-P

Buatois, L. A., \& Mángano, M. G. (2003). Early colonization of the deep sea: Ichnologic evidence of deep-marine benthic ecology from the Early Cambrian of northwest Argentina. Palaios, 18, 572-581. https://doi.org/10.1669/0883-1351(2003)018\&lt;0572:ECOTDS\&g $\mathrm{t} ; 2.0 . \mathrm{CO} ; 2$

Buatois, L. A., \& Mángano, M. G. (2012). The trace-fossil record of organism-matground interactions in space and time. In N. Noffke, \& H. Chafetz (Eds.), Microbial mats in silicilastic depositional systems through time (pp. 15-28). Tulsa, OK: SEPM (Society for Sedimentary Geology) Special Publication.

Buatois, L. A., Narbonne, G. M., Mángano, M. G., Carmona, N. B., \& Myrow, P. (2014). Ediacaran matground ecology persisted into the earliest Cambrian. Nature Communications, 5, 1-5.

Canfield, D. E., Ngombi-Pemba, L., Hammarlund, E. U., Bengtson, S., Chaussidon, M., Gauthier-Lafaye, F., ... El Albani, A. (2013). Oxygen dynamics in the aftermath of the Great Oxidation of Earth's atmosphere. Proceedings of the National Academy of Sciences USA, 110, 16736-16741. https://doi.org/10.1073/pnas.1315570110

Chi Fru, E., Arvestål, E., Callac, N., El Albani, A., Kilias, S., Argyraki, A., \& Jakobsson, M. (2015). Arsenic stress after the Proterozoic glaciations. Scientific Reports, 5, 17789.

Chu, D., Tong, J., Bottjer, D. J., Song, H., Song, H., Benton, M. J., ... Guo, W. (2017). Microbial mats in the terrestrial lower triassic of North China and implications for the Permian-Triassic mass extinction. Palaeogeography, Palaeoclimatology, Palaeoecology, 474, 214-231. https://doi.org/10.1016/j.palaeo.2016.06.013

Chu, D., Tong, J., Song, H., Benton, M. J., Bottjer, D. J., Song, H., \& Tian, L. (2015). Early Triassic wrinkle structures on land: Stressed environments and oases for life. Scientific Reports, 5, 10109. https://doi. org/10.1038/srep10109

Conrad, R., Claus, P., \& Casperb, P. (2010). Stable isotope fractionation during the methanogenic degradation of organic matter in the sediment of an acidic bog lake, Lake Grosse Fuchskuhle. Limnology and Oceanography, 55, 1932-1942. https://doi.org/10.4319/ lo.2010.55.5.1932

Davies, N. S., Liu, A. G., Gibling, M. R., \& Miller, R. F. (2016). Resolving MISS conceptions and misconceptions: A geological approach to sedimentary surface textures generated by microbial and abiotic processes. Earth-Science Reviews, 154, 210-246. https://doi. org/10.1016/j.earscirev.2016.01.005

Decho, A. W. (2000). Microbial biofilms in intertidal systems: An overview. Continental Shelf Research, 20, 1257-1273. https://doi. org/10.1016/S0278-4343(00)00022-4

Dubois, M., Lopez, M., Orberger, B., Rodriguez, C., Boussafir, M., Dreux, G., ... Pambo, F. (2015) The Mn-carbonate rich black shales of the Bangombe Plateau, Francevillian Basin, Gabon. In A. S. André-Mayer, M. Cathelineau, P. Muchez, E. Pirard \& S. Sindern (Eds.), Mineral ressources in a sustainable world. Presented at the Proceedings of the 13th Biennial SGA Meeting, Nancy, France, pp. 1905-1908.

El Albani, A. E., Bengtson, S., Canfield, D. E., Bekker, A., Macchiarelli, R., Mazurier, A., ... Meunier, A. (2010). Large colonial organisms with coordinated growth in oxygenated environments $2.1 \mathrm{Gyr}$ ago. Nature, 466, 100-104. https://doi.org/10.1038/nature09166

El Albani, A., Bengtson, S., Canfield, D. E., Riboulleau, A., Rollion Bard, C., Macchiarelli, R., ... Bekker, A. (2014). The 2.1 Ga old Francevillian biota: Biogenicity, taphonomy and biodiversity. PLoS ONE, 9, e99438. https://doi.org/10.1371/journal.pone.0099438

Eriksson, P. G., Sarkar, S., Samanta, P., Banerjee, S., Porada, H., \& Catuneanu, O. (2010). Paleoenvironmental context of microbial mat-related structures in siliciclastic rocks. In J. Seckbach, \& A. Oren (Eds.), Microbial mats: Modern and ancient microorganisms in stratified 
systems (pp. 71-108). Dordrecht, the Netherlands: Springer. https:// doi.org/10.1007/978-90-481-3799-2

Farquhar, J., Zerkle, A. L., \& Bekker, A. (2011). Geological constraints on the origin of oxygenic photosynthesis. Photosynthesis Research, 107, 11-36. https://doi.org/10.1007/s11120-010-9594-0

Flannery, D. T., \& Walter, M. R. (2012). Archean tufted microbial mats and the Great Oxidation Event: New insights into an ancient problem. Australian Journal of Earth Sciences, 59, 1-11. https://doi.org/10.1080 /08120099.2011.607849

Flood, B. E., Bailey, J. V., \& Biddle, J. F. (2014). Horizontal gene transfer and the rock record: Comparative genomics of phylogenetically distant bacteria that induce wrinkle structure formation in modern sediments. Geobiology, 12, 119-132. https://doi.org/10.1111/gbi.12072

Gancarz, A. J. (1978). U-Pb age (2.05 × 109 years) of the Oklo uranium deposit. Presented at the The Natural Fission Reactors: Annual International Atomic Energy Agency Conference, Vienna, Austria, pp. 513-520.

Garlick, W. G. (1988). Algal mats, load structures, and synsedimentary sufides in revett quartzites of Montana and Idaho. Economic Geology, 83, 1259-1278. https://doi.org/10.2113/gsecongeo.83.6.1259

Gauthier-Lafaye, F. (2006). Time constraint for the occurrence of uranium deposits and natural nuclear fission reactors in the Paleoproterozoic Franceville Basin (Gabon). Geological Society of America Memoirs, 198, 157-167.

Gauthier-Lafaye, F., \& Weber, F. (1989). The Francevillian (lower proterozoic) uranium ore deposits of Gabon. Economic Geology, 84, 22672285. https://doi.org/10.2113/gsecongeo.84.8.2267

Gauthier-Lafaye, F., \& Weber, F. (2003). Natural nuclear fission reactors: Time constraints for occurrence, and their relation to uranium and manganese deposits and to the evolution of the atmosphere. Precambrian Research, 120, 81-100. https://doi.org/10.1016/ S0301-9268(02)00163-8

Gehling, J. G. (1999). Microbial mats in terminal Proterozoic siliciclastics; Ediacaran death masks. Palaios, 14, 40-57. https://doi. org $/ 10.2307 / 3515360$

Gerdes, G. (2007). Structures left by modern microbial mats in their host sediments. In J. Schieber, P. K. Bose, P. G. Eriksson, S. Banerjee, S. Sarkar, W. Altermann, \& O. Catuneanu (Eds.), Atlas of microbial mat features preserved within the siliciclastic rock record (pp. 5-38). Amsterdam, the Netherlands: Elsevier.

Gerdes, G., Claes, M., Dunajtschik-Piewak, K., Riege, H., Krumbein, W. E., \& Reineck, H.-E. (1993). Contribution of microbial mats to sedimentary surface structures. Facies, 29, 61. https://doi.org/10.1007/ BF02536918

Gerdes, G., Klenke, T., \& Noffke, N. (2000). Microbial signatures in peritidal siliciclastic sediments: A catalogue. Sedimentology, 47, 279-308.

Gerdes, G., Krumbein, W. E., \& Reineck, H.-E. (1994). Microbial mats as architects of sedimentary surface structures. In W. E. Krumbein, D. M. Paterson, \& L. J. Stal (Eds.), Biostabilization of sediments (pp. 165182). Oldenburg, Germany: Bibliotheks und Informationsystem der Carl von Ossietzky Universität Oldenberg (BIS)-Verlag.

Gingras, M., Hagadorn, J. W., Seilacher, A., Lalonde, S. V., Pecoits, E., Petrash, D., \& Konhauser, K. O. (2011). Possible evolution of mobile animals in association with microbial mats. Nature Geoscience, 4, 372-375. https://doi.org/10.1038/ngeo1142

Grazhdankin, D., \& Gerdes, G. (2007). Ediacaran microbial colonies: Ediacaran microbial colonies. Lethaia, 40, 201-210. https://doi. org/10.1111/j.1502-3931.2007.00025.x

Hagadorn, J. W., \& Bottjer, D. J. (1997). Wrinkle structures: Microbially mediated sedimentary structures common in subtidal siliciclastic settings at the Proterozoic-Phanerozoic transition. Geology, 25, 1047. https://doi.org/10.1130/0091-7613(1997)025\&lt;104 7:WSMMSS\&gt;2.3.CO;2

Hill, C., Corcoran, P. L., Aranha, R., \& Longstaffe, F. J. (2016). Microbially induced sedimentary structures in the Paleoproterozoic, upper
Huronian Supergroup, Canada. Precambrian Research, 281, 155-165. https://doi.org/10.1016/j.precamres.2016.05.010

Holland, H. D. (2002). Volcanic gases, black smokers, and the Great Oxidation Event. Geochimica et Cosmochimica Acta, 66, 3811-3826. https://doi.org/10.1016/S0016-7037(02)00950-X

Homann, M., Heubeck, C., Airo, A., \& Tice, M. M. (2015). Morphological adaptations of 3.22 Ga-old tufted microbial mats to Archean coastal habitats (Moodies Group, Barberton Greenstone Belt, South Africa). Precambrian Research, 266, 47-64. https://doi.org/10.1016/j. precamres.2015.04.018

Horie, K., Hidaka, H., \& Gauthier-Lafaye, F. (2005). U-Pb geochronology and geochemistry of zircon from the Franceville series at Bidoudouma, Gabon. Presented at the The 15th Annual Goldschmidt Conference, Moscow, ID.

Immenhauser, A. (2009). Estimating palaeo-water depth from the physical rock record. Earth-Science Reviews, 96, 107-139. https://doi. org/10.1016/j.earscirev.2009.06.003

Jungblut, A. D., Hawes, I., Mackey, T. J., Krusor, M., Doran, P. T., Sumner, D. Y., ... Goroncy, A. K. (2016). Microbial mat communities along an oxygen gradient in a perennially ice-covered Antarctic lake. Applied and Environmental Microbiology, 82, 620-630. https://doi. org/10.1128/AEM.02699-15

Karhu, J. A., \& Holland, H. D. (1996). Carbon isotopes and the rise of atmospheric oxygen. Geology, 24, 867-870. https://doi.org/10.1130/ 0091-7613(1996)024\&lt;0867:CIATRO\&gt;2.3.CO;2

Konhauser, K. O., Lalonde, S. V., Planavsky, N. J., Pecoits, E., Lyons, T. W., Mojzsis, S. J., ... Bekker, A. (2011). Aerobic bacterial pyrite oxidation and acid rock drainage during the Great Oxidation Event. Nature, 478, 369-373. https://doi.org/10.1038/nature10511

Kovalchuk, O., Owttrim, G. W., Konhauser, K. O., \& Gingras, M. K. (2017). Desiccation cracks in siliciclastic deposits: Microbial mat-related compared to abiotic sedimentary origin. Sedimentary Geology, 347, 67-78. https://doi.org/10.1016/j.sedgeo.2016.11.002

Lekele Baghekema, S. G., Lepot, K., Riboulleau, A., Fadel, A., Trentesaux, A., \& El Albani, A. (2017). Nanoscale analysis of preservation of ca. 2.1 Ga old Francevillian microfossils, Gabon. Precambrian Research, 301, 1-18. https://doi.org/10.1016/j.precamres.2017.08.024

Lyons, T. W., Reinhard, C. T., \& Planavsky, N. J. (2014). The rise of oxygen in Earth's early ocean and atmosphere. Nature, 506, 307-315. https://doi.org/10.1038/nature13068

Mariotti, G., Pruss, S. B., Perron, J. T., \& Bosak, T. (2014). Microbial shaping of sedimentary wrinkle structures. Nature Geoscience, 7, 736740. https://doi.org/10.1038/ngeo2229

Mata, S. A., \& Bottjer, D. J. (2009). The paleoenvironmental distribution of Phanerozoic wrinkle structures. Earth-Science Reviews, 96, 181195. https://doi.org/10.1016/j.earscirev.2009.06.001

Matsushita, M., Hiramatsu, F., Kobayashi, N., Ozawa, T., Yamazaki, Y., \& Matsuyama, T. (2004). Colony formation in bacteria: Experiments and modeling. Biofilms, 1, 305-317. https://doi.org/10.1017/ S1479050505001626

McNevin, D. B., Badger, M. R., Whitney, S. M., von Caemmerer, G. G., Tcherkez, G. G., \& Farquhar, G. D. (2007). Differences in carbon isotope discrimination of three variants of D-ribulose-1,5-bisphosphate carboxylase/oxygenase reflect differences in their catalytic mechanisms. Journal of Biological Chemistry, 282, 36068-36076. https://doi. org/10.1074/jbc.M706274200

Meyer, M., Xiao, S., Gill, B. C., Schiffbauer, J. D., Chen, Z., Zhou, C., \& Yuan, X. (2014). Interactions between Ediacaran animals and microbial mats: Insights from Lamonte trevallis, a new trace fossil from the Dengying Formation of South China. Palaeogeography, Palaeoclimatology, Palaeoecology, 396, 62-74. https://doi. org/10.1016/j.palaeo.2013.12.026

Mouélé, I. M., Dudoignon, P., El Albani, A., Meunier, A., Boulvais, P., Gauthier-Lafaye, F., ... Cuney, M. (2014). 2.9-1.9 Ga paleoalterations of Archean granitic basement of the Franceville basin (Gabon). Journal 
of African Earth Sciences, 97, 244-260. https://doi.org/10.1016/j. jafrearsci.2014.04.027

Ngombi Pemba, L. (2014). Géochimie et minéralogie des formations argileuses $(2.2-2.0 \mathrm{Ga})$ du bassin de Franceville au Gabon: fluctuations de l'oxygène atmosphérique, chimie des océans et diagenèse au Paléoprotérozoïque.

Ngombi-Pemba, L., Albani, A. E., Meunier, A., Grauby, O., \& GauthierLafaye, F. (2014). From detrital heritage to diagenetic transformations, the message of clay minerals contained within shales of the Palaeoproterozoic Francevillian basin (Gabon). Precambrian Research, 255, 63-76. https://doi.org/10.1016/j.precamres.2014.09.016

Noffke, N. (2009). The criteria for the biogeneicity of microbially induced sedimentary structures (MISS) in Archean and younger, sandy deposits. Earth-Science Reviews, 96, 173-180. https://doi.org/10.1016/j. earscirev.2008.08.002

Noffke, N. (2010). Geobiology. Berlin, Heidelberg, Germany: Springer Berlin Heidelberg. https://doi.org/10.1007/978-3-642-12772-4

Noffke, N., Christian, D., Wacey, D., \& Hazen, R. M. (2013). Microbially induced sedimentary structures recording an ancient ecosystem in the ca. 3.48 billion-year-old dresser formation, Pilbara, Western Australia. Astrobiology, 13, 1103-1124. https://doi.org/10.1089/ ast.2013.1030

Noffke, N., Gerdes, G., Klenke, T., \& Krumbein, W. E. (1997). A microscopic sedimentary succession of graded sand and microbial mats in modern siliciclastic tidal flats. Sedimentary Geology, 110, 1-6. https:// doi.org/10.1016/S0037-0738(97)00039-0

Noffke, N., Gerdes, G., Klenke, T., \& Krumbein, W. E. (2001). Microbially induced sedimentary structures - A new category within the classification of primary sedimentary structures: Perspectives. Journal of Sedimentary Research, 71, 649-656. https://doi. org/10.1306/2DC4095D-0E47-11D7-8643000102C1865D

Noffke, N., Knoll, A. H., \& Grotzinger, J. P. (2002). Sedimentary controls on the formation and preservation of microbial mats in siliciclastic deposits: A case study from the Upper Neoproterozoic Nama Group, Namibia. Palaios, 17, 533-544. https://doi.org/10.1669/0883-1351(2 002)017\&It;0533:SCOTFA\&gt;2.0.CO;2

Ossa Ossa, F.-G. (2010). Etude multi-approches du bassin sédimentaire paléoprotérozoïque (2.1-2.4 Ga) de Franceville au Gabon: les environnements sédimentaires et l'impact des paléocirculations de fluides.

Parize, O., Feybesse, J.-L., Guillocheau, F., \& Mulder, T. (2013). Were the 2.1-Gyr fossil colonial organisms discovered in the Francevillian basin (Palaeoproterozoic, Gabon) buried by turbidites? Comptes Rendus Geoscience, 345, 101-110. https://doi.org/10.1016/j. crte.2013.01.001

Partin, C. A., Bekker, A., Planavsky, N. J., Scott, C. T., Gill, B. C., Li, C., ... Lyons, T. W. (2013). Large-scale fluctuations in Precambrian atmospheric and oceanic oxygen levels from the record of $U$ in shales. Earth and Planetary Science Letters, 369-370, 284-293. https://doi. org/10.1016/j.epsl.2013.03.031

Partin, C. A., Lalonde, S. V., Planavsky, N. J., Bekker, A., Rouxel, O. J., Lyons, T. W., \& Konhauser, K. O. (2013). Uranium in iron formations and the rise of atmospheric oxygen. Chemical Geology, 362, 82-90. https://doi.org/10.1016/j.chemgeo.2013.09.005

Pecoits, E., Konhauser, K. O., Aubet, N. R., Heaman, L. M., Veroslavsky, G., Stern, R. A., \& Gingras, M. K. (2012). Bilaterian burrows and grazing behavior at $>585$ million years ago. Science, 336, 1693-1696. https://doi.org/10.1126/science.1216295

Pfluger, F. (1999). Matground structures and redox facies. Palaios, 14, 25. https://doi.org/10.2307/3515359

Porada, H., \& Bouougri, E. H. (2007). Wrinkle structures-a critical review. In J. Schieber, P. K. Bose, P. G. Eriksson, S. Banerjee, S. Sarkar, W. Altermann, \& O. Catuneanu (Eds.), Atlas of microbial mat features preserved within the siliciclastic rock record (pp. 135-144). Amsterdam, the Netherlands: Elsevier.
Porada, H., Bouougri, E. H., \& Ghergut, J. (2007). Hydraulic conditions and mat-related structures in tidal flats and coastal sabkhas. In J. Schieber, P. K. Bose, P. G. Eriksson, S. Banerjee, S. Sarkar, W. Altermann, \& O. Catuneanu (Eds.), Atlas of microbial mat features preserved within the siliciclastic rock record (pp. 258-265). Amsterdam, the Netherlands: Elsevier.

Porada, H., Ghergut, J., \& Bouougri, E. H. (2008). Kinneyia-type wrinkle structures - Critical review and model of formation. Palaios, 23, 65-77. https://doi.org/10.2110/palo.2006.p06-095r

Quandt, L., Gottschalk, G., Ziegler, H., \& Stichler, W. (1977). Isotope discrimination by photosynthetic bacteria. FEMS Microbiology Letters, 1, 125-128. https://doi.org/10.1111/j.1574-6968.1977.tb00596.x

Reineck, H.-E., \& Singh, I. B. (1980). Depositional sedimentary environments. Berlin, Heidelberg, Germany: Springer Berlin Heidelberg,. https://doi.org/10.1007/978-3-642-81498-3

Reyes, K., Gonzalez, N. I., Stewart, J., Ospino, F., Nguyen, D., Cho, D. T., ... Johnson, H. A. (2013). Surface orientation affects the direction of cone growth by Leptolyngbya sp. Strain C1, a likely architect of coniform structures octopus spring (Yellowstone National Park). Applied and Environmental Microbiology, 79, 1302-1308. https://doi. org/10.1128/AEM.03008-12

Reynaud, J.-Y., Trentesaux, A., El Albani, A., Aubineau, J., Ngombi-Pemba, L., Guiyeligou, G., ... Weber, F. (2017). Depositional setting of the $2.1 \mathrm{Ga}$ Francevillian macrobiota (Gabon): Rapid mud settling in a shallow basin swept by high-density sand flows. Sedimentology, 65 , 670-701.

Runnegar, B. N., \& Fedonkin, M. A. (1992). Proterozoic metazoan body fossils. In J. W. Schopf, \& C. Klein (Eds.), The proterozoic biosphere: A multidisciplinary study (pp. 369-388). Cambridge, UK: Cambridge University Press.

Sagemann, J., Bale, S. J., Briggs, D. E., \& Parkes, R. J. (1999). Controls on the formation of authigenic minerals in association with decaying organic matter: An experimental approach. Geochimica et Cosmochimica Acta, 63, 1083-1095. https://doi.org/10.1016/S0016-7037(99)00087-3

Sarkar, S., Banerjee, S., Samanta, P., Chakraborty, N., Chakraborty, P. P., Mukhopadhyay, S., \& Singh, A. K. (2014). Microbial mat records in siliciclastic rocks: Examples from Four Indian Proterozoic basins and their modern equivalents in Gulf of Cambay. Journal of Asian Earth Sciences, 91, 362-377. https://doi.org/10.1016/j.jseaes.2014.03.002

Sarkar, S., Banerjee, S., Samanta, P., \& Jeevankumar, S. (2006). Microbial mat-induced sedimentary structures in siliciclastic sediments: Examples from the 1.6 Ga Chorhat Sandstone, Vindhyan Supergroup, MP, India. Journal of Earth System Science, 115, 49-60. https://doi. org/10.1007/BF02703025

Sarkar, S., Bose, P., Samanta, P., Sengupta, P., \& Eriksson, P. (2008). Microbial mat mediated structures in the Ediacaran Sonia Sandstone, Rajasthan, India, and their implications for Proterozoic sedimentation. Precambrian Research, 162, 248-263. https://doi.org/10.1016/j. precamres.2007.07.019

Sarkar, S., Choudhuri, A., Mandal, S., \& Eriksson, P. G. (2016). Microbial mat-related structures shared by both siliciclastic and carbonate formations. Journal of Palaeogeography, 5, 278-291. https://doi. org/10.1016/j.jop.2016.05.001

Schidlowski, M. (1988). A 3,800-million-year isotopic record of life from carbon in sedimentary rocks. Nature, 333, 313-318. https://doi. org/10.1038/333313a0

Schidlowski, M. (2001). Carbon isotopes as biogeochemical recorders of life over 3.8 Ga of Earth history: Evolution of a concept. Precambrian Research, 106, 117-134. https://doi.org/10.1016/ S0301-9268(00)00128-5

Schieber, J. (1998). Possible indicators of microbial mat deposits in shales and sandstones: Examples from the Mid-Proterozoic Belt Supergroup, Montana, U.S.A. Sedimentary Geology, 120, 105-124. https://doi.org/10.1016/S0037-0738(98)00029-3 
Schieber, J. (1999). Microbial mats in terrigenous clastics; the challenge of identification in the rock record. Palaios, 14, 3-12. https://doi. org/10.2307/3515357

Schwark, L., \& Frimmel, A. (2004). Chemostratigraphy of the Posidonia Black Shale, SW-Germany II. Assessment of extent and persistence of photic-zone anoxia using aryl isoprenoid distributions. Chemical Geology, 206, 231-248. https://doi.org/10.1016/j. chemgeo.2003.12.008

Sheldon, N. D. (2012). Microbially induced sedimentary structures in the ca. $1100 \mathrm{Ma}$ terrestrial midcontinent rift of North America. In N. Noffke, \& H. S. Chafetz (Eds.), Microbial mats in silicilastic depositional systems through time (pp. 153-162). Tulsa, OK: SEPM (Society for Sedimentary Geology) Special Publication.

Shepard, R. N., \& Sumner, D. Y. (2010). Undirected motility of filamentous cyanobacteria produces reticulate mats: Motility produces reticulate mats. Geobiology, 8, 179-190. https://doi. org/10.1111/j.1472-4669.2010.00235.x

Sim, M. S., Liang, B., Petroff, A. P., Evans, A., Klepac-Ceraj, V., Flannery, D. T., ... Bosak, T. (2012). Oxygen-dependent morphogenesis of modern clumped photosynthetic mats and implications for the Archean stromatolite record. Geosciences, 2, 235-259. https://doi.org/10.3390/ geosciences2040235

Simpson, E. L., Heness, E., Bumby, A., Eriksson, P. G., Eriksson, K. A., Hilbert-Wolf, H. L., ... Okafor, O. J. (2013). Evidence for 2.0 Ga continental microbial mats in a paleodesert setting. Precambrian Research, 237, 36-50. https://doi.org/10.1016/j.precamres.2013.08.001

Sumner, D. Y., Hawes, I., Mackey, T. J., Jungblut, A. D., \& Doran, P. T. (2015). Antarctic microbial mats: A modern analog for Archean lacustrine oxygen oases. Geology, 43, 887-890. https://doi.org/10.1130/ G36966.1

Taj, R. J., Aref, M. A. M., \& Schreiber, B. C. (2014). The influence of microbial mats on the formation of sand volcanoes and mounds in the Red Sea coastal plain, south Jeddah, Saudi Arabia. Sedimentary Geology, 311, 60-74. https://doi.org/10.1016/j.sedgeo.2014.06.006

Thomas, K., Herminghaus, S., Porada, H., \& Goehring, L. (2013). Formation of Kinneyia via shear-induced instabilities in microbial mats. Philosophical Transactions of the Royal Society A: Mathematical, Physical and Engineering Sciences, 371, 20120362. https://doi. org/10.1098/rsta.2012.0362
Velde, B. D., \& Meunier, A. (2008). The origin of clay minerals in soils and weathered rocks. Berlin, Germany: Springer-Verlag. https://doi. org/10.1007/978-3-540-75634-7

Wacey, D. (2009). Early life on earth: A practical guide. Topics in geobiology. Dordrecht, the Netherlands: Springer. https://doi. org/10.1007/978-1-4020-9389-0

Walcott, C. D. (1914). Cambrian geology and palaeontology III, No. 2. Precambrian, Algonkian algal flora. Smithsonian Miscellaneous Collections, 64, 77-156.

Weber, F. (1969). Une série précambrienne du Gabon: le Francevillien. Sédimentologie, géochimie, relations avec les gîtes minéraux associés.

Wilmeth, D. T., Dornbos, S. Q., Isbell, J. L., \& Czaja, A. D. (2014). Putative domal microbial structures in fluvial siliciclastic facies of the Mesoproterozoic (1.09 Ga) Copper Harbor Conglomerate, Upper Peninsula of Michigan, USA. Geobiology, 12, 99-108. https://doi. org/10.1111/gbi.12071

Yang, H., Chen, Z.-Q., \& Fang, Y. (2017). Microbially induced sedimentary structures from the $1.64 \mathrm{Ga}$ Chuanlinggou Formation, Jixian, North China. Palaeogeography, Palaeoclimatology, Palaeoecology, 474, 7-25. https://doi.org/10.1016/j.palaeo.2016.04.038

\section{SUPPORTING INFORMATION}

Additional supporting information may be found online in the Supporting Information section at the end of the article.

How to cite this article: Aubineau J, El Albani A, Chi Fru E, et al. Unusual microbial mat-related structural diversity 2.1 billion years ago and implications for the Francevillian biota. Geobiology. 2018;16:476-497. https://doi.org/10.1111/ gbi.12296 